ARLA

34,3

368

Received 21 July 2020

Revised 5 November 2020

18 January 2021

Accepted 23 February 2021

\section{Challenging the context: mumpreneurship, copreneurship and sustainable thinking in the entrepreneurial process of women - a case study in Ecuador}

\section{Desafiando el contexto: mumpreneurship, copreneurship y pensamiento sostenible en el proceso emprendedor de las mujeres - Estudio de casos en Ecuador}

\author{
María Eulalia Chávez Rivera \\ Business School, Universidad de Monterrey, Monterrey, Mexico, and \\ María del Mar Fuentes Fuentes and Jenny María Ruiz-Jiménez \\ Business Organization, Universidad de Granada, Granada, Spain
}

\begin{abstract}
Purpose - The purpose of this article is to determine the factors in the context of entrepreneurship that are evident in Ecuador, a country that has the highest rate of female entrepreneurship worldwide with $34 \%$ according to the Global Entrepreneurship Monitor (GEM) (2019).

Design/methodology/approach - A qualitative study was carried out with 39 cases, applying in-depth personal interviews and focus groups to selected cases in the main cities of Ecuador.
\end{abstract}

\section{JEL Classification — L26, M21, N26, Q56, Z13}

(C) María Eulalia Chávez Rivera, María del Mar Fuentes Fuentes and Jenny María Ruiz-Jiménez. Published by Emerald Publishing Limited. This article is published under the Creative Commons Attribution (CCBY 4.0) licence. Anyone may reproduce, distribute, translate and create derivative works of this article (for both commercial and non-commercial purposes), subject to full attribution to the original publication and authors. The full terms of this licence may be seen at http://creativecommons.org/licences/ by/4.0/legalcode

This paper forms part of a special section "Entrepreneurship in Latin American Countries: Evidence from GEM and GUESSS Project", guest-edited by Gianni Romaní, Rodrigo Varela and Izaías Martins.

The authors would like thank the three blinded reviewers and editors whose contributions enhanced the quality of this paper. The authors gratefully acknowledge the financial support lent by the Spanish Ministry of Science, Innovation and Universities [ECO2016-80677-R] and the European Union (FEDER Grants). The authors are grateful to the Economic Promotion Agency of the Municipality of Quito CONQUITO, the Chamber of Commerce and the US Embassy with its AWE - DreamBuilder programme, the Entrepreneurship Centre at Universidad de Guayaquil, for having collaborated with databases and contacts, as well as with their facilities to carry out the field research. 
Findings - The results suggest that "mumpreneurship", copreneurship and sustainable thinking arise in response to the environment. Deepening then in the perspective of the 5M proposes by Brush et al. (2009) that give us a framework of the macroenvironment of women entrepreneurship and offers a holistic understanding of women's entrepreneurship, adding a sixth "M" which is "Environmental Thinking" or the environmental thinking that is present in the current context.

Originality/value - This article is one of the first to analyse the context of female entrepreneurship in Ecuador and determine the context factors that influence the identification of opportunities and the exploitation of entrepreneurial opportunities. It also presents the expectations and challenges of the women who shape the authors' case studies and give voice to Ecuadorian women. Consequently, this research will support the configuration of policies that supports each of the stages of women's entrepreneurial processes.

Keywords Women entrepreneurship, Mumpreneurs, Mumpreneurship, Sustainable thinking,

Entrepreneurial process

Paper type Case study

\section{Resumen}

Propósito - Este artículo pretende determinar los factores del contexto del emprendimiento que se evidencian en el Ecuador, país que ostenta la tasa más alta de emprendimiento femenino a nivel mundial con un $34 \%$ de acuerdo al GEM (2019).

Diseño/metodología/enfoque - Se realizó un estudio cualitativo con 39 casos, aplicando entrevistas personales a profundidad y grupos focales a casos seleccionados en las principales ciudades del Ecuador.

Resultados - Los resultados sugieren que el "mumpreneurship", el copreneurship y el pensamiento sostenible surgen como respuesta al entorno. Profundizando entonces en la perspectiva de las 5Ms propuesta por Brush et al. (2009) que ofrece una comprensión holística del emprendimiento de mujeres, añadiendo una sexta "M" que es el "Medioambiental Thinking" o el pensamiento ambiental que está presente en el contexto estudiado.

Originalidad/valor - Este artículo es uno de los primeros en analizar el contexto del emprendimiento femenino en Ecuador y determinar los factores del contexto que influyen en la identificación y en la explotación de oportunidades emprendedoras. Además presenta las expectativas y retos de las mujeres que configuran nuestros casos de estudio y dan voz a las mujeres ecuatorianas. En consecuencia nuestra investigación servirá de apoyo para la configuración de políticas que apoyen cada una de las etapas del proceso emprendedor de las mujeres.

Palabras clave Emprendimiento de mujeres, mumpreneurs, Mumpreneurship, copreneurship, Pensamiento sostenible, Proceso emprendedor

Tipo de papel Caso de estudio

\section{Introduction}

A widespread current discussion involves the value of entrepreneurship in the economic development of different countries. However, despite the fact that a number of studies have revealed the positive effects of entrepreneurship on increasing national productivity, the debate has not yet reached any significant level in developing economies (Álvarez and Grazzie, 2018). In response to this, governments worldwide are gradually beginning to support entrepreneurship by promoting public policies, thereby progressively demonstrating a source of higher incomes, increased national and international trade flows, innovation and reduced unemployment. As a result, entrepreneurship has been gaining popularity, with more than half of the global population in 52 countries considering entrepreneurship as a good career option (GEM, 2018).

However, over the years we have shaped an image of the "entrepreneur" as being associated with masculinity and traits characteristic of men such as the strength and tenacity that "should" accompany an entrepreneur. Indeed, women have had to earn their place in the entrepreneurial environment through their contribution to job creation, innovation and wellbeing (Kelley et al., 2015), and they are currently one of the fastest growing entrepreneurial populations in the world (De Vita et al., 2013). Along with this increasing number of businesses started and managed by women, there has been a growing interest from academia. This has led to an increase in the number of research studies on women entrepreneurs, which focus on understanding the internal motivations of women entrepreneurs rather than the environment in which they develop (Arenius and Minniti, 2005; Jennings and Brush, 2013). 
ARLA 34,3
Hence, the importance of understanding the context, a multiple phenomenon that intervenes in entrepreneurship directly and indirectly as it offers a lens through which to consider how individuals interact with situations in their environment and how situations influence the individual (Welter, 2011), providing a broader and more varied perspective on the entrepreneurial phenomenon (Welter, 2011; Zahra et al., 2014).

Gender affects the way in which an environment is perceived. For several authors, there are substantial differences in the situations to which men and women are exposed. These include institutional variables that affect the extent of female entrepreneurship in different countries (Welter et al., 2003; Minniti and Arenius, 2003; Welter, 2011; Ruíz-Arroyo et al., 2017), social variables such as work-family conflict studied by Shelton (2006) and contact networks (Welter and Trettin, 2006; De Carolis et al., 2009), among others. Other studies focus on the particular context of different countries; for example, Álvarez et al. (2012) studied the context of female entrepreneurship in Spain, and, more recently, Aidis (2016) investigated the innovation environment for female entrepreneurship in Latin America.

Despite the progress of the studies mentioned above, the literature on context and female entrepreneurship in South America is still scarce and has focused only on specific dimensions, predominantly studies on the institutional context. We therefore developed our research to help fill this gap in the field of study while at the same time heeding the call of several authors (Minniti and Naude, 2010; De Vita, 2013; Kelley et al., 2015; Welter et al., 2014) who point out the importance of addressing the different contexts of women's entrepreneurship and its temporal dimension. The purpose of this study is therefore to identify the contextual factors that influence the entrepreneurial process through the two stages proposed by Shane and Venkataraman (2000), namely the identification and exploitation of entrepreneurial opportunities, which will be analysed from a woman entrepreneur's perspective. To this end, we conducted a qualitative research study using the case study methodology proposed by (Yin, 2017) in the context of Ecuador.

The paper is structured as follows. The first section sets out the theoretical framework and reviews the main results provided by the literature on female entrepreneurship in relation to the role of the context and its dimensions. Next, we present the research design and methodology followed by a description of the cases studied with their particular characteristics. We then present the results of the coding process, data analysis and comparison with the literature. Finally, we reflect on our findings, put forward propositions and discuss their implications in the academic, economic and social fields.

\section{Literature review \\ 2.1 Context}

Context has been studied from different perspectives, including recent work in sociology (Simpson and Willer, 2008), psychology (Wagner and Rush, 2000) and organisational behaviour (Rousseau and Fried, 2001; Johns, 2006).

Business contexts present considerable novelty and are constantly changing due to the dynamism of the actors and processes involved (Zahra and Wright, 2011). They span a wide spectrum as there are differences in both perception and analysis (Baker and Welter, 2018). Steyaert and Katz (2004) previously defined context as a more complex social phenomenon and subdivided it into social context, institutional context and spatial context. Zahra and Wright (2011) identified four dimensions of context: spatial, time, practice and change, and later, Zahra et al. (2014) extended this to include business characteristics such as organisational, ownership and governance dimensions. Welter (2011), in her study focusing on women entrepreneurs, states that the different contexts respond to the questions: where, when and why do entrepreneurship occur; who or whom are involved in the entrepreneurial process and when does this process take place? The study examines the 
historical and temporal dimensions transversally present in the two stages of the entrepreneurial process-identification and exploitation of the entrepreneurial opportunity-and how the entrepreneurial process is carried out (Shane and Venkataraman, 2000).

Table 1 provides a systematisation of the basis of our research, which is the context perspective proposed by Welter (2011).

Our research is based on Welter's (2020) premise that contexts are interdependent and that temporal dimensions are transversal to each contextual factor. Thus, we address the temporal dimension as a cross-cutting factor in the stages of the entrepreneurial process, i.e. the identification and exploitation of the entrepreneurial opportunity (Shane and Venkataraman, 2000).

2.1.1 Social context. The individual is an eminently social being. This context can undoubtedly be one of the most important for women entrepreneurs whose family and social ties drive or limit them when setting up their own business (Manolova et al., 2008). This has been studied by Minniti (2009), who highlights networks, role models and women's role in the family as significant factors.

2.1.1.1 Contact networks and role models. Networks provide a mechanism for integration and serve as the social platform of the business (Anderson et al., 2010). They strengthen the entrepreneur by providing meaning, identity and resources (Jack et al., 2008). Networks have been previously studied by Davidsson and Honig (2003), Minniti (2009), Langowitz and Minniti (2007), Blenkinsopp and Owens (2010), Anderson et al. (2010), Ruiz-Arroyo et al. (2015), Naguib and Jamali (2015), among others. And they have been analysed from other areas of knowledge where they have been defined as a determining factor in women's entrepreneurship given the importance of knowing other women entrepreneurs when deciding to undertake an entrepreneurial venture (Minniti, 2009).

Concerning contact networks, several studies also analyse the closeness and frequency of relationships with the network (Ruiz-Arroyo et al., 2015), pointing out their levels of influence depending on these factors.

Studies by Minniti and Arenius (2003), on the other hand, highlight the differences in entrepreneurs' networks according to gender. They point out that men generally pursue

\begin{tabular}{|c|c|c|}
\hline $\begin{array}{l}\text { Dimensions of the } \\
\text { context }\end{array}$ & General & Examples \\
\hline Social (Where?) & Networking, home and family & $\begin{array}{l}\text { Network structure; density and } \\
\text { frequency of relationships; household } \\
\text { and family composition and roles }\end{array}$ \\
\hline Institutional(Where?) & $\begin{array}{l}\text { Culture and society, political and } \\
\text { economic system }\end{array}$ & $\begin{array}{l}\text { Social attitudes and norms; legal } \\
\text { regulations; policies and support } \\
\text { measures }\end{array}$ \\
\hline Spatial (Where?) & $\begin{array}{l}\text { Geographical environment: countries, } \\
\text { communities and neighbourhoods, } \\
\text { industrial districts and clusters }\end{array}$ & $\begin{array}{l}\text { Characteristics of the physical location of } \\
\text { the business; infrastructure; } \\
\text { characteristics of local communities and } \\
\text { regions }\end{array}$ \\
\hline Business (Where?) & Industry, markets & $\begin{array}{l}\text { Life cycle stage of industries and } \\
\text { markets; number and nature of } \\
\text { competitors }\end{array}$ \\
\hline $\begin{array}{l}\text { Historical and } \\
\text { temporal dimensions } \\
\text { (Where?) }\end{array}$ & Marked by a temporal space & \\
\hline
\end{tabular}

Note(s): *Adapted from Welter (2011), Welter et al. (2014)

Table 1.

Dimensions of the entrepreneurial context 
ARLA 34,3

hierarchical alliances oriented towards short-term interests, while women create affective ties and pursue long-term and more solid relationships. For a woman entrepreneur, networks offer support during the process of identifying and exploiting the opportunity and accompaniment throughout the life cycle of the new business (Johnson et al., 2003).

In countries with less-developed economies, women entrepreneurs' networks tend to be smaller, less geographically mobile and less formal than those of their male peers (Minniti and Arenius, 2003). Moreover, regardless of whether the country's per capita income is high or low, there is a strong tendency towards a positive relationship between meeting other women entrepreneurs and starting a new business (Minniti, 2009). However, this is more evident in countries with low-income economies where there are a greater number of women entrepreneurs who say they know other entrepreneurs (Minniti et al., 2005). Hence, the importance granted to "Networking" by the Global Entrepreneurship Index - GEI (Ács et al., 2018) as one of its pillars for women's entrepreneurship.

2.1.1.2 Women's role in the family. A key contribution that research on women's entrepreneurship has made over the years is to recognise that the phenomenon of entrepreneurship is not gender-neutral. It is embedded in socially constructed belief systems associated with behaviours and roles that are considered appropriate for each sex (Jennings and Brush, 2013). Women's role in the family has historically been established by society, in turn, influenced by religion and culture, where the responsibilities of caring for the home have weighed heavily on women. If we analyse the Latin American context, it is clear that both motherhood and looking after the home play a decisive role and are considered to be the essential duty of women (Lamas, 2008). Indeed, in some cultures, love is not the only primary motivation for women to carry out what they consider to be their maternal duties; morals and social and religious values come into play as well. (Palomar Verea, 2005). In themselves, these aspects are part of the subordinate role in which women were considered "natural" and men "cultural", by virtue of their natural biological role (Rosaldo et al., 1974). Although this has been progressively diminishing with the increasing presence of women in the public sphere, there are still many differences in terms of the performance of motherhood in rural and urban environments. Indeed, by the age of $22,20 \%$ of women in urban areas are already mothers, while this figure rises to between 60 and $80 \%$ in rural populations, often causing women to drop out of school (Lamas, 2008) and making their lives and those of their families more precarious, given the high levels of poverty in such areas. Many women have had to resort to making so-called "sacrifices" in order to reverse their subordinate roles and improve their personal and family standards of living, by choosing between being a full-time mother and achieving fulfilment in the workplace. This has not been easy either, as motherhood is still conceived with prejudices and stereotypes, including in terms of maternity leave (Heller, 2012), and where reaching a high hierarchical position is often a condition for childless women. Thus, according to the neoclassical theory of human capital, which explains gender segregation in the labour market, women tend to have fewer opportunities to reach high positions because of the belief of company managers that they will be employed while they are still childless; therefore, the company will waste time, money and effort in training female employees who will eventually leave. This paradigm is present even if the woman announces that she is not willing to leave her job. Finally, women are not hired for jobs that have been traditionally defined for men (Loprest, 1992).

As they experience a major conflict between work and family roles than men (Welter, 2004), the results of which are often negative (Jennings and Brush, 2013; Hammer et al., 2004), explains why women have had to carefully consider the typical roles associated with their family and domestic responsibilities before making a decision about entrepreneurship (Welter et al., 2003).

For Shelton (2006), work-family conflict is defined as a form of role conflict that arises because the pressures emanating from one role are incompatible with those of another. 
Numerous studies then support the fact that women are motivated to start their own businesses in the hope of achieving a better work-family balance (Brush, 1992; Shelton, 2006; Jennings and Brush, 2013). Accordingly, Brush's (1992) "integrated perspective" points out that many women entrepreneurs see their businesses as part of their lives rather than as separate economic entities, tending to intertwine business activities with their family responsibilities, of which child-rearing is one.

2.1.2 Spatial context. Spatial context is part of the context perspective studied by Steyaert and Katz (2004), Welter (2011), Welter et al. (2014) and refers to the physical place where entrepreneurship takes place and how it influences the identification and exploitation of entrepreneurial opportunities. The spatial context has not been widely studied; however, feminist economic theory has identified the importance of place in understanding gender relations (Gibson-Graham, 1996). This has highlighted how differences between men and women are constituted through space (Harrison et al., 2020). Thus, the geographical region is related to the culture and, in turn, the male and female behaviours accepted by different societies. At the same time, it is considered a key level at which an economy's capacity for development is determined, and, in the field of entrepreneurship, it analyses the phenomena of women entrepreneurs' natural environment and the influences, factors and forces that affect their behaviours and their business results (Harrison et al., 2020).

2.1.3 Institutional context. The institutional context has been theorised and studied through informal and formal factors. The informal aspects comprise the constraints that come from information received over the years by society and which we call culture (North, 1997). Formal factors complement the effectiveness of informal constraints and are laws and public policies. Both formal and informal institutions can influence or constrain the identification and exploitation of entrepreneurial opportunities (Welter, 2011).

Previous studies indicate that formal institutions create areas of opportunity for entrepreneurship, while informal ones moderate the collective and individual perception of those opportunities (Welter and Smallbone, 2008). Moreover, they tend to interact, as, for example, in Latin America where there is a strong influence of informal institutions on formal ones (Hechavarría, 2016). Thus, culture can influence the evolution of government policies in different countries.

Culture refers to the set of values and norms that guide the behaviour of members of a society (Granato et al., 1996). It is transmitted through teaching, imitation and values (Boyd and Richerson, 2009). The influence of culture on entrepreneurship can be observed in societies whose entrepreneurial motivations might be due to their culture rather than economic factors (Boettke and Coyne, 2009; Reynolds et al., 1994; Jack and Anderson, 2002). For Varela (2001), values such as hard work, achievement, motivation or wealth generation are part of the behavioural pattern of individuals in different countries. Thus, culture shapes the thoughts, feelings and reactions of individuals (McGrath and Mc Millan, 1992). In terms of culture and gender roles, in most societies, the responsibility for taking care of the household and caring for children, the elderly or the sick falls on women, while men tend to be assigned the role of provider. Women are therefore allocated part-time, low-skilled jobs, which allow them to fulfil "their roles". As a result, women opt for lower levels of specialisation as they do not require it to fit the jobs that they are "fit for", even though they receive lower pay and compensation. Accordingly, women will find it more difficult to achieve similar human capital as men.

Moreover, in societies where male values dominate the culture, women's participation in entrepreneurship decreases as they feel very distant from social norms (Quevedo et al., 2010). Rubio and Esteban (2016) present the Hofstede scale (1983) in which he analysed the countries considered culturally more masculine or feminine. The author divides countries into four categories: feminine countries (Sweden, Norway, Finland, etc.), moderately feminine countries (Chile, Portugal, Panama, Peru, Brazil, Spain), moderately masculine countries (Argentina, 
ARLA 34,3
India, Ecuador, Colombia, Mexico, Italy, etc.) and masculine countries (Hungary, Japan, Slovakia). Female countries are those where the gender gaps are the smallest and vice versa (Rubio and Esteban, 2016). Behaviours that have been incorporated into the masculine (instrumental) domain are strength, assertiveness, achievement orientation, etc. and those related to femininity (expressiveness) are nurturance, modesty, concern for quality of life, etc. (Hofstede and McCrae, 2004). This may have an impact on the performance of companies established in different countries with greater or lesser masculinity traits (Martín-Ugedo et al., 2019). In this sense, the socio-cultural expectations for each member of a country will depend to some extent on their gender (García-Campos, 2008). These cultural differences influence gender discrimination in the workplace, and there are several related theories, including the theory of statistical discrimination, which becomes evident when two individuals with the same qualifications are treated differently solely on the basis of their gender (Lago, 2002).

On the other hand, authors such as Scott (1995) and Kostova (1997) studied the institutional environment from three dimensions: regulatory, cognitive and normative. Business laws and policies enacted by a country's government are part of the regulatory dimension. The normative dimension is framed by the rules for entrepreneurial activities in a given region (Kostova, 1997). In the context of female entrepreneurship, the regulatory dimension includes the gender-specific laws in the General Constitution that guarantee equal opportunities for women and men. The normative dimension includes labour market regulations that grant equal access to jobs and family policies such as specific tax regulations and in some countries childcare and property rights for women (Manolova, 2008; Welter and Smallbone, 2008).

The influence of these dimensions on the identification and exploitation of opportunities is evidenced by the availability of capital, access to credit granted by the state, the strength of support institutions and fiscal support measures. In itself, a positive institutional context reduces the levels of uncertainty that escalate throughout the entrepreneurial process (Li et al., 2015).

2.1.4 Business context. The business context refers to the influence of market, industry and competition on the identification and exploitation of entrepreneurial opportunities (Welter, 2011). The market is part of the 5Ms that influence female entrepreneurship, along with money, management, motherhood and the meso/macro environment (Brush et al., 2009). The market is the basic element for creating a new business (Shane, 2003) as the identification of entrepreneurial opportunities is closely related to the market environment in which the business is developed (Brush et al., 2009).

The entrepreneur's ability to perceive the business environment and, in turn, interpret it has been studied by Herron and Robinson (1993), Ardichvili and Cardozo (2000). The latter indicated that the ability to successfully recognise a business opportunity is influenced by entrepreneurial awareness among other factors. Thus, the exploitation of the opportunity and subsequent actions or behaviours will depend on this process (Man and Lau, 2005).

Another factor to consider in the business context is innovation by introducing novel products, without which a business would not be competitive. In this regard, the Global Entrepreneurship Monitor (GEM) in its special edition "Women" (2018) points out that women who start their businesses say that their products or services are innovative. This is confirmed by the 74 economies studied by the GEM, where women entrepreneurs are $5 \%$ more likely to innovate than men (Kelley et al., 2017).

2.1.5 Interacting contexts. Noting the relevance of interacting contexts in better understanding entrepreneurship, Welter (2011) stresses the importance of the multilayered approach by emphasising the proximal social interactions and distal political and cultural systems previously referred to by Mowday and Sutton (1993).

In this sense, while motherhood and family roles pertain to the social context, they could also be considered part of the informal factors of the institutional context through culture 
influenced by the historical and temporal dimension, thus demonstrating the interaction of contexts. This shows the importance of cultural legacy in the definition of family roles where being a mother influences many actions, especially in the entrepreneurial process (Brush et al., 2009; Minniti 2009). Thus, for women who have become mothers, the identification of entrepreneurial opportunities could be linked to the satisfaction of their need for selffulfilment, which, according to Down and Warren (2008), could be linked to the "career narrative".

2.1.5.1 Mumpreneurship. In their quest to maintain a career while balancing work and family, women who are mothers have given rise to the term "mumpreneurs", which Ekinsmyth (2011, p. 105) defines as "an individual who discovers and exploits new business opportunities in a social and geographical context that seeks to integrate the demands of motherhood and business ownership".

The terms "mumpreneur" for entrepreneurial mothers or "mumpreneurship" for the act of entrepreneurship that accompanies motherhood have attracted media attention since their inception, with campaigns seeking to encourage women to embrace entrepreneurship as an alternative way to achieve a work-life balance (Eikhof et al., 2013). This concept was first pioneered in the United Kingdom in 2011 when, according to Ekinsmyth (2011), a Google search on the word "mumpreneur" returned more than 700,000 results, whereas a year earlier it was barely more than 120,000 .

For Welter et al. (2014), while the study of mumpreneurs has emerged from forums, blogs and other community discussion spaces, it is only in the last 14 years or so that have seen the emergence of academic studies distinguishing mothers who run their own businesses and engage in childcare from women entrepreneurs, implying a limitation even as far as the concept itself. The concept has been shaped within the "new feminism" field, where women are called upon to embrace motherhood and shape the demands of business in the best possible way (Welter et al., 2014). Meanwhile, a study by Duberley and Carrigan (2012) demonstrated the importance that mumpreneurs gave to being considered "good mothers" by limiting the growth of their businesses as a way to efficiently fulfil both roles, even if it represents many hours of work. This last aspect represents a common factor in studies of women's entrepreneurship (Baines and Wheelock, 1998; Gurstein, 1996).

Likewise, the formal factors of the institutional context such as laws and public policies interact with the social context where the option of entrepreneurship is socially accepted and legally validated in some countries if it is undertaken together with a partner. To this, we must add the growing discrimination that affects aspects such as the wage gap, the employment gap, the high rates of unemployment, underemployment and women's reduced access to management and decision-making positions.

2.1.5.2 Copreneurship. Given the discriminating factors and determinants at social and cultural level, women would opt for starting entrepreneurship with their partner and become "copreneurs", a term that, according to Blenkinsopp and Owens (2010), was coined by Barnett and Barnett (1988) to define those couples where both are involved in the business and share responsibilities for its operation and management.

Copreneurship is thus defined as entrepreneurship created by romantic business partners (Jurik et al., 2019). Recent studies point to the positive effects of copreneurship, such as being based on a relationship of support and cooperation not only financially but also in terms of time and effort, which could contribute to business development (Machek and Hnilica, 2015), as could the input of both visions. Among the negative aspects would be the division of roles and decision-making as currently the husband still tends to be the boss (Machek and Hnilica, 2015).

The interaction of social contexts with networks and role models, the institutional context with the cultural heritage associated with multiple customs and traditions and the 
ARLA 34,3 geographical location as part of the spatial context and the innovation culture of today's business context provide the basis for sustainable thinking and, based on this, the development of sustainable entrepreneurship.

2.1.5.3 Sustainable entrepreneurship as a result of sustainable thinking. For Johns (2017), sustainable thinking is a line that is framed within the study of entrepreneurship contexts and draws the attention of scholars, as the sustainable development paradigm accepts that there is a certain compatibility between environmental concerns and economic development. Thus, the geographical location of a firm may make it more or less likely for it to achieve sustainability goals (Gallo et al., 2018).

Authors such as Jambor and Lindner (2018) include social and ecological responsibility within the business model of new companies, highlighting female entrepreneurship because according to Hechavarria et al. (2012) and Jennings and Brush (2013), companies led by women are more sensitive and inclined to adopt social causes than those led by men. Thus, female entrepreneurship should be understood from its holistic nature where the identification of the entrepreneurial opportunity would lie in the determination of social or environmental problems while its exploitation would be based on the desire to provide solutions to these problems and at the same time obtain economic benefits.

It is therefore in this interplay between sustainable thinking and the exploitation of opportunity that the concept of sustainable entrepreneurship was born (Johnson and Schaltegger, 2020; Muñoz and Cohen, 2018). This new concept of sustainable entrepreneurship is

focused on the preservation of nature, life support, and community in the pursuit of perceived opportunities to bring into existence future products, processes, and services for gain, where gain is broadly construed to include economic and non-economic gains to individuals, the economy, and society (Shepherd and Patzelt, 2011, p. 142).

Thus, sustainable entrepreneurship combines the achievement of social, environmental and economic goals in an integrated and comprehensive manner in pursuit of the future progress and the well-being of future generations (Tilley and Young, 2009).

2.1.6 Research context: Ecuador. Ecuador stands out for its high rates of female entrepreneurship with $51.67 \%$ OER, which exceeds male entrepreneurship that stands at $48.33 \%$, according to the 2017 GEM Ecuador (Lasio et al., 2018). This phenomenon has already attracted the attention of authors such as Brush et al. (2018), Arraíz (2018), Khan (2019) who cite studies by the GEM (2018) in which Ecuador is noted as the country with the highest rate of female entrepreneurship worldwide.

Although the laws on entrepreneurship in Ecuador do not specifically address women's entrepreneurship, they do show concern for reducing the wage gap of $21.9 \%$ and the employment gap of 35.5\% between men and women (Senplades, 2017). However, at cultural level, barely $17 \%$ of the population supports women's entrepreneurship (Ács et al., 2018). This may be due to the country's moderate level of masculinity (Hofstede, 1983) validated in the study conducted by Rubino and Esteban (2016) where Ecuador is ranked 63rd on the masculinity scale, with a gender gap of 0.17 . Consequently, it ranks 82 out of 149 countries in economic participation and opportunities for women with a ratio of 0.283 in political representation and female empowerment (World Economic Forum, 2018).

\section{Methodology}

\subsection{Research design}

We chose the inductive multi-case design (Yin, 2017), as it broadens our understanding of the contextual factors that influence female entrepreneurship. The level of analysis is the Ecuadorian context that has been presented above, specifically in the cities of Quito, Guayaquil, Cuenca and Riobamba, which contain a high concentration of urban 
entrepreneurship. The unit of analysis is women entrepreneurs in micro and small enterprises (MSMEs) in urban environments. We have opted for the urban context, as we believe that recent studies have focused on enterprises in rural and community settings. However, research on women entrepreneurs in urban areas is scarce.

\subsection{Case selection}

Our research consists of a detailed field study involving the participation of women entrepreneurs. In the first instance, four cities in Ecuador were chosen, according to the Women concentration of MSMEs. We chose 39 cases, of which 14 were participants of the CONQUITO "Mujeres emprendiendo con éxito" programme and the rest were participants of the Academy for Women Entrepreneurs (AWE) DreamBuilder programme. For these cases, we applied the literal replication criterion (Yin, 2017) as they were cases of women entrepreneurs from Quito participating in training programmes, and we therefore expected similar results. Literal replication logic applied to context analysis can be used to examine the similarities or differences that would exist between the different contextual factors such as government policies, access to resources, networks, family roles, physical environment, business environment, gender gap, culture and society.

We then selected a further 11 cases of women entrepreneurs from the other three cities and treated these using a theoretical replication design (Yin, 2017). Our reason for doing so was that, despite being in the same country, some cities outside the capital would perceive the influence of the environment differently. One example is that women in these other cities may not have had the same concern or opportunities for training. We therefore split these cases based on the assumption that the two groups have different types of conditions and on the fact that we wanted to have subgroups covering each type of condition (Yin, 2017).

\subsection{Data gathering}

Data were collected through two instruments: in-depth, semi-structured, face-to-face interviews (25 participants - see Annex 1) and focus groups (14 participants - see Annex 2). The instruments were applied between August 2017 and August 2019, the interview guide was developed based on the questionnaire provided in the NES (National Experts Survey) form applied by GEM Mujer Chile 2017 (Mandakovic et al., 2017). The questions focused on environmental conditions are as follows: Do you know about credit options and government subsidies for new and growing businesses? Do you think that support for new and growing businesses is a high priority for policies at the national or local government level? Do you know or have you participated in educational policies that offer attention to entrepreneurship and the creation of new businesses? Questions on their perceptions of entrepreneurship and the creation of new businesses were also included and inquired into whether they consider entrepreneurship as a socially accepted work option (by family and friends); whether women are encouraged to be entrepreneurs; whether they consider that men and women have the same opportunities for entrepreneurship and which of the two start businesses more out of necessity; and whether they have access to social services to continue working after becoming mothers.

Both in-depth interview and focus groups have been recommended (Bird and Brush, 2002; Duberley and Carrigan, 2012) to "explore the quieter, more feminine and personal end of entrepreneurship". Accordingly, we used several informants as suggested by Eisenhardt and Graebner (2007) in order to limit bias and gather diverse perspectives on the phenomenon. We first gathered secondary information from media and websites on women's entrepreneurship programmes in Ecuador.

In the first phase, we asked the heads of CONQUITO's Women in Successful Entrepreneurship Programme and the AWE DreamBuilder Programme to provide us with 
ARLA 34,3

a list of women entrepreneurs who have excelled in their programme, respectively. We received a list of 30 winners or finalists in the competitions run by the CONQUITO programme and 31 participants in the latest AWE training. We then collected information about their businesses from websites and checked this information against the SRI (Internal Revenue Service) public database. The information obtained allowed us to determine the type of business activity, the year of creation and the active status of the enterprises. In accordance with our approach, we selected those cases in which the enterprises had survived at least their 1st year of life. Next, we looked for women entrepreneurs in the remaining three cities. This information was obtained from the SRI in a search based on the gender of the MSME owner. We selected these according to similar criteria and parameters to those applied in the first groups. The women entrepreneurs in the province (11) were first contacted by telephone to arrange a personal interview at their business. A summary of the cases studied (interviews and focus groups, respectively) can be found in Tables A1 and A2.

The in-depth interviews lasted between 1.5 and $2 \mathrm{~h}$, encouraging participants to develop a personal narrative (Larty and Hamilton, 2011) through a theoretically validated interview guide. The focus group had a similar guide, but this was adapted according to previous results (Silverman and Marvasti, 2008 internal validation). The meeting lasted 4 h. From the active position of the participants, we were able to corroborate King's (2004) finding that participants enjoy the experience and that it can help them to clear up doubts about particular issues.

In a final phase, we conducted participant observation (Waddington, 2004) because we were interested in the way people act, think or feel, and we wanted to share their experience. To do so, the researchers participated in a monthly "Café de Emprendedoras" organised by the Association of Women Entrepreneurs of Ecuador and the CONQUITO and AWE trainings, respectively. They interacted with the participants and learned first-hand about their concerns and expectations in their own environment (Taylor and Bogdan, 1984).

\subsection{Data analysis}

We conducted the data analysis using the constant comparative method (Strauss and Corbin, 1990), which begins by labelling raw data into basic units of analysis. It is designed to develop consistent descriptions of social phenomena that allow us to make discoveries and generate theories about them. Based on this method, we began to identify theoretical categories and make comparisons between categories prior even to the formal analysis of the data. By doing this, we were able to develop associated coding criteria. For the coding process, we paid special attention to avoid the "holistic bias", as the tendency of researchers to see patterns beyond the obvious (Gibbert and Ruirok, 2010). For this, we used triangulation of data obtained from primary sources such as interviews with our unit of analysis, research on websites of support programmes for women entrepreneurs and direct participatory observation.

We then considered the reports obtained for the preparation of the semi-structured script applied to the focus group. To do so, we adapted the script of the individual interviews according to the preliminary findings. We did this as an independent measure of construct validity. In some of the cases when we found counter-evidence or new constructs, we recoded the individual and group interview transcripts.

Based on these final coding criteria, all data (interviews, observation, and focus groups) were included in Atlas.ti. software, which allowed on-screen coding and comparison between categories. Thus, we established networks and determined codes resulting from interactions and could graphically evidence co-occurrences in network graphs. Finally, the analysis allowed us to assess the degree to which some codes were the cause, were related to or were the result of empirically constructed propositions in terms of our central research question. 
The first-order codes were established on the basis of theory as were the social, institutional, spatial and business contexts. As the research progressed, second-order codes were established, including mumpreneurship, copreneurship, sustainable thinking, access to credit, discrimination, innovation, sustainable entrepreneurship, opportunity identification, opportunity exploitation, role models, motivation, partners, proprietorship, institutional support, family support, obstacles to entrepreneurship, government policies, etc. The results of this research highlight the following: Mumpreneurship had 35 co-occurrences, copreneurship 27 co-occurrences, sustainable entrepreneurship 44 co-occurrences, when related to opportunity identification (41) and opportunity exploitation (28).

\section{Results}

Following the theoretical framework adopted, we analysed the contextual factors that affect women's entrepreneurial process. According to the time dimension identified by Welter (2011), we analysed our results based on the two stages of the entrepreneurial process: the identification of the opportunity and the exploitation of the opportunity, as an approximation of the transversal time dimension.

\subsection{Opportunity identification}

To identify a business opportunity is to consider that, at some point, the market supply is not satisfying a latent need and that by satisfying it, a profit could be made. Thus, for some of the cases studied, the social, spatial and business contexts present a framework for the identification of opportunities through previous experiences in the case of mumpreneurs and as the result of information and cognitive capacities in sustainable entrepreneurship.

4.1.1 Social context and mumpreneurship. One factor that stands out in our research is family roles. These roles are very well established in Ecuador and have led companies created by women-mothers to take over market spaces with businesses that often operate within their homes, providing the opportunity for what is known as mumpreneurship. In total, $64 \%$ of the women entrepreneurs in our study cited motherhood as their main motivation for starting a business. In Table 2, we analyse 15 representative cases of this concept.

For these "mumpreneurs", the need for time, the search for work flexibility and childcare concerns are part of the motivations for setting up a business (Figure 1).

When asked whether they were satisfied with their decision to become entrepreneurs, $99 \%$ of them said yes. Many indicated that they would never work as employees again. They feel that they can balance their family and personal life. However, they stress that the work of an entrepreneur is not easy and that they have to dedicate a lot of time to the business. This may be one of the reasons why these businesses tend to grow as the children grow up and no longer need as much attention from their mother:

I thought I would have more free time but when you take on this responsibility there are so many more hours of work outside of working hours, unlike in any other job... I did not think we would grow as quickly as we did. . . in any case I'm satisfied and I know that I somehow manage to attend my daughters' school events... Ana (Child care centre).

Mumpreneurs have been able to identify opportunities through their experiences of motherhood:

It all started when I became a mother. Four months after I had my baby, I was already thinking about what else to do besides being a mother, because my life changed completely and from having a very busy day, non-stop, hardly ever being in the office, and then being at home $24-7$, it was like I needed 


\begin{tabular}{|c|c|c|c|c|c|c|}
\hline \multirow[b]{2}{*}{$\begin{array}{l}\text { ARLA } \\
34,3\end{array}$} & & & & & & \\
\hline & Mumpreneur & Age & $\begin{array}{l}\text { Number of } \\
\text { children }\end{array}$ & $\begin{array}{l}\text { Previous } \\
\text { work }\end{array}$ & Entrepreneur in ... & $\begin{array}{l}\text { Reason for starting } \\
\text { entrepreneurship }\end{array}$ \\
\hline \multirow[b]{3}{*}{380} & Neyla & 33 & 2 & Assistant & Catering service & \multirow{6}{*}{$\begin{array}{l}\text { Flexibility at work and time to } \\
\text { take care of the children } \\
\text { Improve household income and } \\
\text { care for their children } \\
\text { No dependence on anyone, time } \\
\text { for childcare } \\
\text { Need for time, to dedicate } 100 \% \\
\text { of their time to their children } \\
\text { Work and at the same time be } \\
\text { able to devote herself to her } \\
\text { children } \\
\text { Need time for her daughters }\end{array}$} \\
\hline & Amada & 36 & 2 & Services & Sale of clothing & \\
\hline & Jessenia & 30 & 2 & Student & $\begin{array}{l}\text { Building } \\
\text { maintenance }\end{array}$ & \\
\hline & María Isabel & 35 & 2 & $\begin{array}{l}\text { Hotel } \\
\text { services }\end{array}$ & $\begin{array}{l}\text { Sale of processed } \\
\text { food }\end{array}$ & \\
\hline & Cristina & 33 & 2 & N/A & & \\
\hline & Ana & 42 & 2 & Teacher & $\begin{array}{l}\text { Textile } \\
\text { manufacturing of } \\
\text { uniforms }\end{array}$ & \\
\hline & Sandra & 31 & 1 & Teacher & Child care centre & \multirow{3}{*}{$\begin{array}{l}\text { Devote the time required for her } \\
\text { daughter } \\
\text { Avoid being an employee and } \\
\text { flexibility of time for her } \\
\text { children }\end{array}$} \\
\hline & Isabel & 36 & 2 & Teacher & $\begin{array}{l}\text { Air Yoga workshop } \\
\text { Manufacture of } \\
\text { ecological nappies }\end{array}$ & \\
\hline & María Cecilia & 33 & 1 & $\begin{array}{l}\text { Public } \\
\text { relations }\end{array}$ & & \\
\hline & Gabriela & 29 & 1 & $\begin{array}{l}\text { Tourism } \\
\text { guide }\end{array}$ & $\begin{array}{l}\text { Online job placement } \\
\text { platform for mothers }\end{array}$ & \multirow{4}{*}{$\begin{array}{l}\text { Helping other mothers and } \\
\text { being able to dedicate time to her } \\
\text { daughter } \\
\text { Lack of work opportunities with } \\
\text { flexible working hours and } \\
\text { concern for her daughter }\end{array}$} \\
\hline & Ximena & 46 & 1 & Police & $\begin{array}{l}\text { Innovative heritage } \\
\text { tourism routes }\end{array}$ & \\
\hline & Carmen & 43 & 3 & Editor & $\begin{array}{l}\text { Manufacture of } \\
\text { natural cosmetics } \\
\text { Manufacture of } \\
\text { natural skin care } \\
\text { products }\end{array}$ & \\
\hline & Doris & 47 & 1 & $\begin{array}{l}\text { Web page } \\
\text { design }\end{array}$ & & \\
\hline & Senaida & 36 & 3 & $\begin{array}{l}\text { Travel } \\
\text { agency }\end{array}$ & $\begin{array}{l}\text { Blog on motherhood } \\
\text { and baby care }\end{array}$ & Taking care of her child \\
\hline $\mathrm{T}$ & Erika & 46 & 1 & $\begin{array}{l}\text { Civil } \\
\text { servant }\end{array}$ & $\begin{array}{l}\text { Manufacture of } \\
\text { chocolate bars }\end{array}$ & Time to spend with her children \\
\hline
\end{tabular}

Cases of mumpreneurs Note(s): Data obtained through qualitative research instruments between January 2018 and September 2019

to do something else, so Istarted to look for work options that would provide me with some flexibility so that I could also be at home and do what I like. I studied, I have a master's degree, but I did not find anything, no job gave me those options. María Cecilia (Flexible job placement agency for mothers).

... the ecological nappies business started when I found out from a friend that there was this option. When I was pregnant, I was looking for alternatives to raise my daughter well, but there was no such thing in Ecuador, only in the United States... Isabel (ecological nappies).

Thus, these opportunities would not have been identified without their condition of being mothers and their intention to solve problems in their own market segment.

4.1.2 Spatial and business contexts, and sustainable entrepreneurship. In Ecuador, the spatial context influences opportunity identification. Thus, women entrepreneurs in urban sectors are looking for business models based on sustainable thinking without losing their market orientation. With a view to achieving differentiation in supply, given the Ecuadorian 


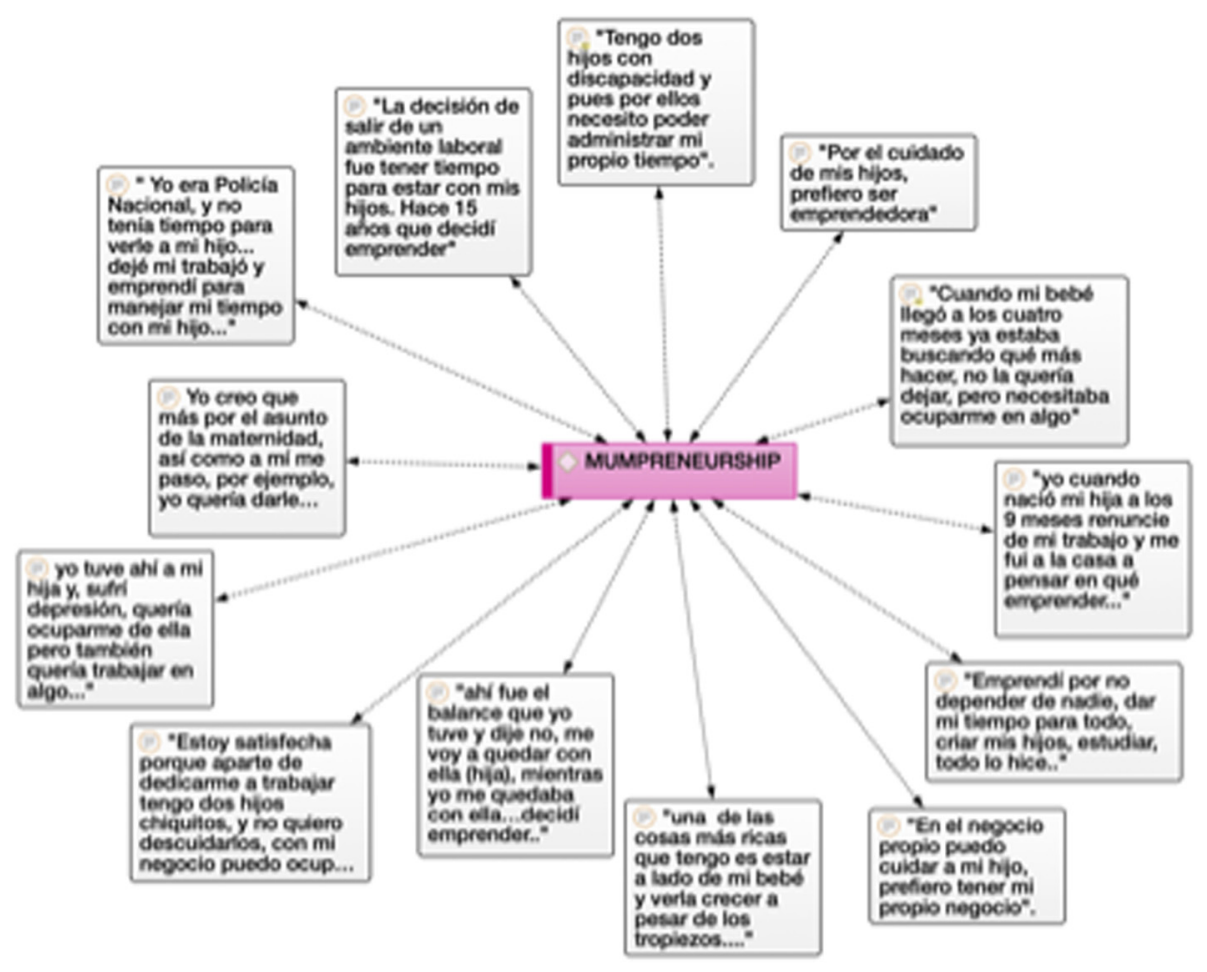

Women
entrepreneurship

381

business context, they seek to innovate and provide alternatives that can be better accepted by their segment. Accordingly, we evaluated the cases in Table 3, based on the three pillars of sustainable development proposed by Ciegis et al. (2009), and included a fourth pillar, which is culture and the revaluation of ancestral knowledge.

Most of the cases comply with all the pillars of sustainable development or are aligned to the social aspect or environmental care. This shows that sustainable thinking has an impact on women developing sustainable entrepreneurship in Ecuador. It stands out that all the participants think that their business contributes, in one way or another, to the improvement of health, well-being and living conditions of the segment they are targeting.

We determined that the identification of a business opportunity arises from the search for information and from the cognitive capacities of the women entrepreneurs to recognise a business opportunity in the solution of a personal problem:

... I started to question myself a lot about everything we put on our bodies every day and what we put on our children, shampoos, creams, deodorants and cosmetics. Then I started to look for options that are not toxic to our health and the environment but I could not find any, so 9 years ago I started to make them at home, then I started to sell them to my relatives, they ordered more and more so then it became my business. . . Carmen (Nátu Natural Cosmetics).

...I could not use soaps with chemical components because of the damage they did to my skin, so I started to make my own natural soaps, and now I sell them... Ana (natural soaps).

...this was born out of a health problem, as I had to consume a large quantity of an imported product that was aloe vera powder, it was very expensive so I decided to make it myself. . . Estefanía (natural nutritional supplements). 
ARLA
34,3

382

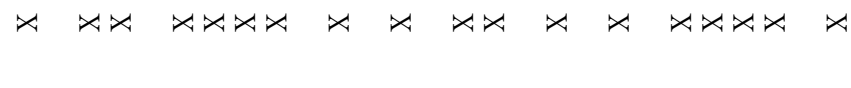

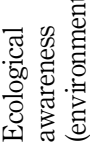

急

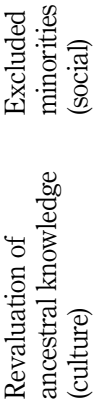

$x x \rtimes x x \quad x \quad x x \quad x \quad x \quad x \quad x$

$x \quad x \quad x \quad x \quad x \quad x x \quad x \quad x \quad x \rtimes x x$

Table 3.

Cases of women

sustainable

entrepreneurs

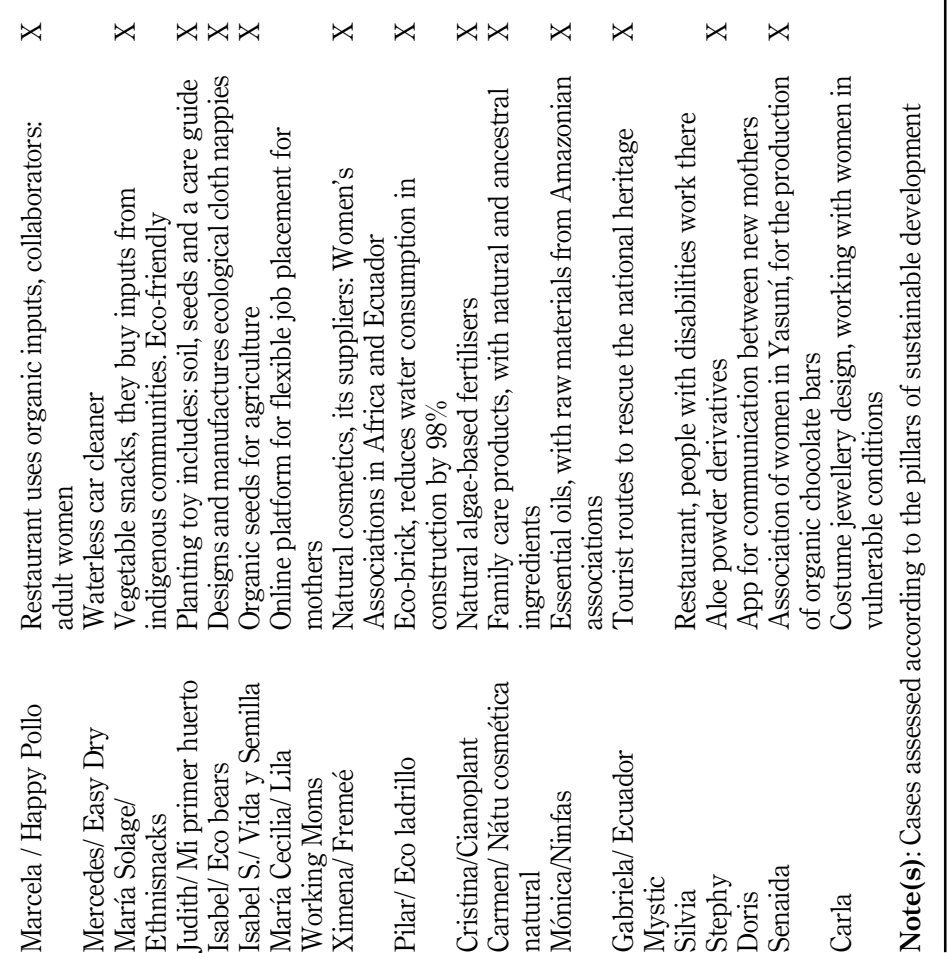


Once the opportunity was identified, they exploited it and created their companies. This was influenced by several factors in the institutional environment, including access to resources and lack of institutional support, resulting in copreneurship.

4.2.1 Institutional and social context and copreneurship. The exploitation of entrepreneurial opportunities is related to the individual's perception of whether or not to take entrepreneurial risks, and this, in turn, is deeply rooted in the culture. In our study sample, $95 \%$ of the participants were practising Catholics, which influences their culture. For them, gender roles are clearly marked by societal acceptance, in which the mother is valued as the primary caregiver. As they themselves say, they married young and have an average of two children. They all affirm that the responsibility of caring for the household falls on women in both urban and rural settings. Under these conditions, it has been difficult for them to find suitable employment. In Ecuador, the unemployment rate in 2019 was $4.6 \%$ for women and $3.3 \%$ for men, who have an adequate employment rate of $44.8 \%, 10 \%$ points higher than that of women (INEC, 2019). Many women entrepreneurs also point to the wage gap- $15 \%$ in the last year - as a problem they have had to face when they have been employed (INEC, 2019). This means that, given the institutional context, women entrepreneurs have had to balance their family role with part-time work due to the need for financial income in their families. Thus, for them entrepreneurship is an option that, for the most part, they have adopted out of necessity (GEM, 2018) and that has gradually become a socially accepted choice, especially when undertaken as a joint venture.

Based on our research, we can deduce that the women entrepreneurs studied do not start up alone (only $3 \%$ do), showing that teaming up with a partner gives them a better perception of their ability to take on the risks involved in setting up a business. This could be due to the influence of role models in the social context. These partners include friends or family members and in most cases, spouses or partners, leading to what is known as copreneurship. This is related to the informal institutional context whereby the culture in Ecuador has moderated women's reliance on support such as a partner, making the entrepreneur more optimistic in her perception of exploiting the opportunity.

Of the cases studied, more than $60 \%$ started a business together with their spouse or partner. Among the main reasons were financial support, ease in the division of roles, trust and teamwork (see Figure 2).

My husband supports me and is basically my right hand. With him, we had to work in the rain, on farms, anywhere, because we started from the bottom ... Cristina (39 years old).

My husband is obviously my main investor; I said let's do it and he agreed and we first looked at how to cut the nappies more efficiently and more quickly... Isabel (ecological nappies).

Our women entrepreneurs in this category (23) are listed in Table 4.

On the other hand, despite the fact that most of the women entrepreneurs studied claim to be the decision-makers in the business, when it comes to establishing hierarchies in the organisation, the cultural pattern is once again marked by the fact that the man has to be the "boss," and so they tend to cede positions of power despite being the ones who identified and took the decision to exploit the business opportunity.

My husband would be the manager and I would be the assistant manager and marketing manager Neyla (catering service).

I am the administrator; Ricardo is the president. . Isabel (seeds and agricultural inputs).

My husband is the president, (...) and I am the legal representative or general manager Gabriela (tourism services). 
ARLA

34,3

384

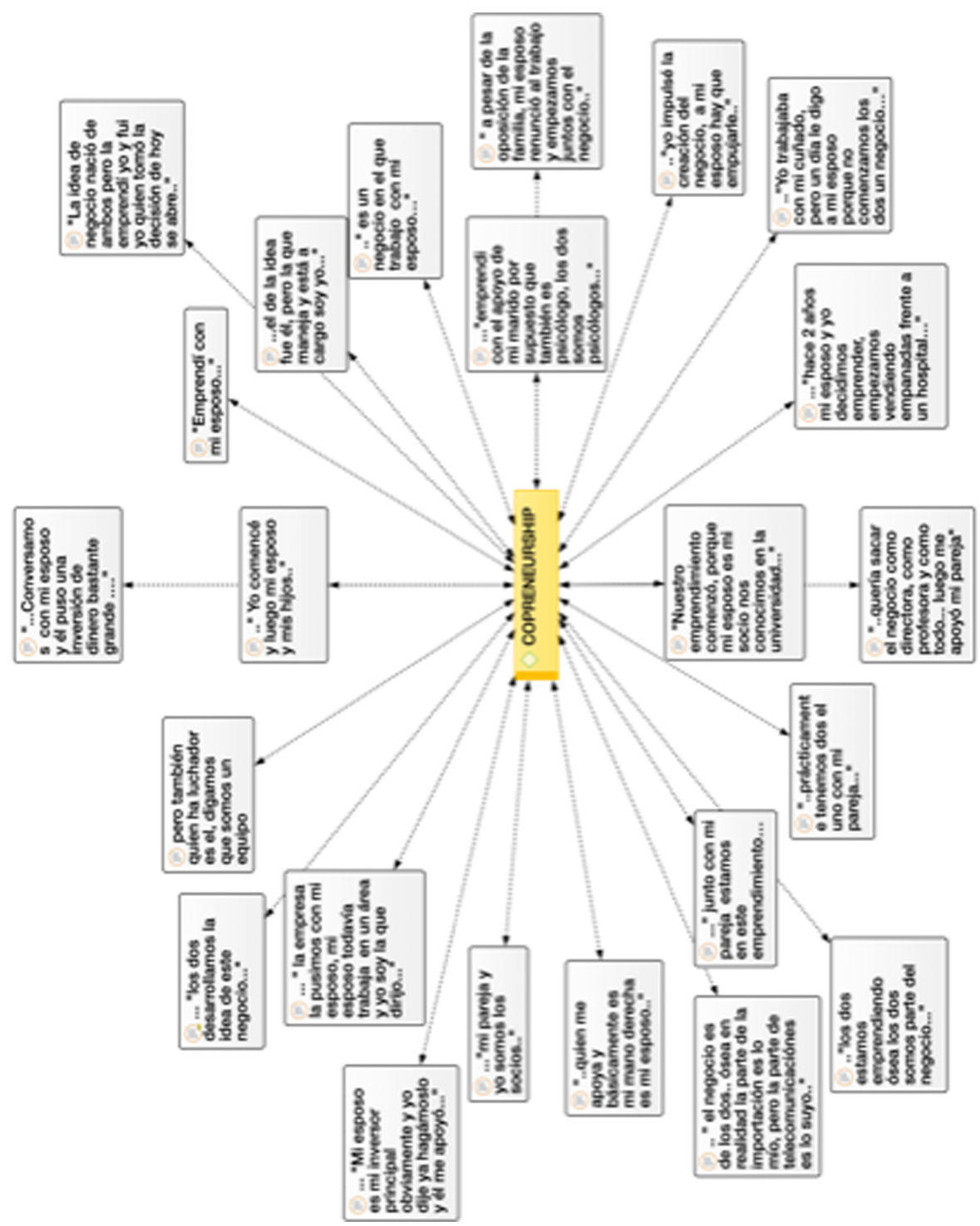

Figure 2.

Copreneurs interviews 


\begin{tabular}{|c|c|c|c|}
\hline Copreneurs & Entrepreneur in . & Started her business with. . & \multirow{2}{*}{$\begin{array}{l}\text { Women } \\
\text { entrepreneurship }\end{array}$} \\
\hline \multirow{5}{*}{$\begin{array}{l}\text { Neyla } \\
\text { Jessenia } \\
\text { María Isabel } \\
\text { Ana } \\
\text { Isabel }\end{array}$} & Catering services & Started her business with her husband & \\
\hline & Building maintenance & Started her business with her husband & \\
\hline & Sale of processed food & Started her business with her husband & \\
\hline & & Started her business with her husband & \\
\hline & $\begin{array}{l}\text { Child care centre } \\
\text { Production of ecological } \\
\text { nappies }\end{array}$ & $\begin{array}{l}\text { Started her business with her husband's support who is her } \\
\text { capitalist partner }\end{array}$ & 385 \\
\hline & Started her business with her husband, who left his job & \\
\hline Mercedes & $\begin{array}{l}\text { Innovative heritage tourism } \\
\text { routes }\end{array}$ & Started her business with her boyfriend & \\
\hline Isabel & Car cleaning product & Started her business with her husband and her siblings & \\
\hline Pilar & Organic seeds for agriculture & Started her business with her husband and her children & \\
\hline Cristina & Ecological bricks & Started her business with her husband & \\
\hline Silvia & Fertilisers based on algae & Started her business with her husband & \\
\hline Stephy & Restaurant & Started her business with her husband & \\
\hline Aída & Aloe powder derivatives & Started her business with her husband & \\
\hline Marcela & Sale of traditional food & Started her business with her husband y her aunts & \\
\hline Cristina & Fast food restaurant & Started her business with her husband's financial support & \\
\hline Sandra & Textile manufacturing & Started her business with her boyfriend's support & \\
\hline Isabel & Centre for Yoga classes & $\begin{array}{l}\text { Started her business with a woman partner and her } \\
\text { husband's financial support }\end{array}$ & \\
\hline Mónica & $\begin{array}{l}\text { Job placement agency for } \\
\text { mothers }\end{array}$ & $\begin{array}{l}\text { Started her business with her husband and Works with } \\
\text { entrepreneurs in Amazonía }\end{array}$ & \\
\hline Erika & Produces essential oils & Started her business with her partner & \\
\hline Diana & $\begin{array}{l}\text { Bocaditos (Argentinean } \\
\text { alfajores) }\end{array}$ & Started her business with her husband and father & \\
\hline $\begin{array}{l}\text { Ana } \\
\text { Verónica }\end{array}$ & $\begin{array}{l}\text { Commercialises technological } \\
\text { products }\end{array}$ & Started her business with her husband's financial support & \\
\hline Jessica & $\begin{array}{l}\text { Manufactures natural } \\
\text { cosmetics }\end{array}$ & Started her business with her husband & \\
\hline Ángela & Canine care & Started her business with her husband and her parents & \\
\hline \multicolumn{3}{|c|}{ Note(s): "Data obtained through qualitative research instruments between January 2018 and September 2019} & Cases copreneurship \\
\hline
\end{tabular}

As a result, Ecuadorian women entrepreneurs find it difficult to assume the leading role that being in charge of the new business implies and tend to relegate themselves to more administrative positions, leaving their husbands or partners with the degree of legal authority in the constitution of the new business. This in turn avoids taking on the risk involved in the legal responsibility of the business.

\section{Discussion}

Contextual factors influence Ecuadorian women's entrepreneurial process, in some cases in the identification and in others in the exploitation of entrepreneurial opportunities to a greater or lesser extent. Figure 3 shows how the linkages between contexts provide new environmental factors that shape the entrepreneurial process.

Mumpreneurship is related to family roles (social context) and the formal and informal factors of the institutional context. This is explained by the fact that although motherhood orients women to fit into a specific role, it is influenced by a lack of government policies for the creation of jobs with flexible working hours, new forms of employment contracts, state programmes that guarantee childcare and longer maternity leave (currently eight weeks). Also consistent is the cultural premise that validates women as mothers dedicated to their homes (Brush, 2014). Accordingly, we develop the following proposition: 


\section{ARLA 34,3}

\section{6}

Figure 3.

Factors arising from linking contexts

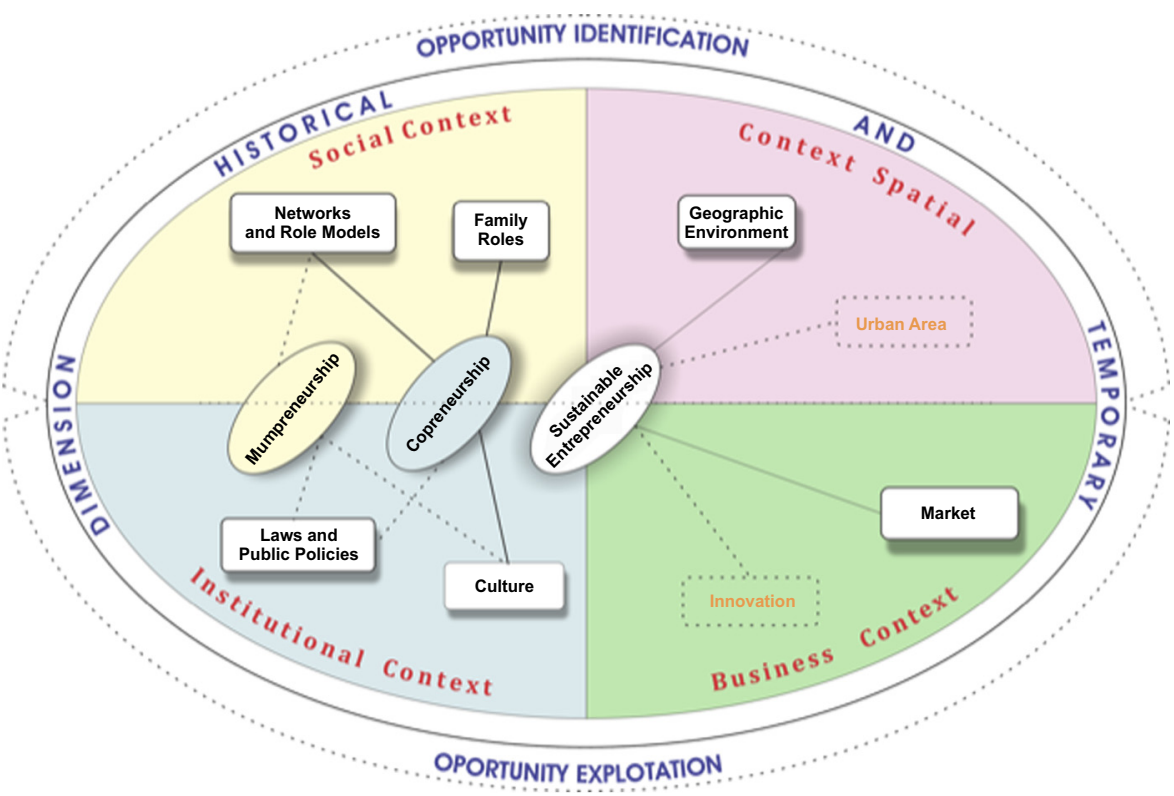

Proposition 1. The interplay of social and institutional contexts provides the basis for mumpreneurship that is strongly influenced by family roles in identifying opportunities, while culture and public laws and policies have a weak link in identifying opportunities and a strong link in exploiting them.

On the other hand, Ecuadorian women entrepreneurs are capable of identifying entrepreneurial opportunities. Their social environment favours them; however, their culture, which values male over female performance in the business sphere, has meant that they do not fully believe in their abilities and avoid taking risks. Thus, in order to move to the next stage of the entrepreneurial process, they require financial resources, time and support. Thus, one option used by women is to start a business as a couple. Thus, the study of copreneurship provides a shift in research on family businesses that has focused primarily on succession (Carter et al., 2001). We developed proposition 2 in this respect:

Proposition 2. Women entrepreneurs are more likely to exploit a business opportunity if they are accompanied in the process, so that entrepreneurship includes a strong link with culture and society and a weak link with laws and public policies, providing copreneurship to overcome the risks of entrepreneurship and obtain support.

Furthermore, in Ecuador, the sustainable thinking of women entrepreneurs is a factor that cuts across historical and temporal dimensions and all contexts. In the social context, family roles raise women's awareness, enabling them to identify opportunities to solve their own problems. In the institutional context, there is evidence of the revaluation of ancestral knowledge and of cultural revival. In terms of the spatial context, women in urban sectors have a higher level of preparation and orient their actions towards production with less environmental impact. The business context directly influences the exploitation of the opportunity, serving a market segment sensitive to social and environmental impact that seeks innovative products and services, providing the basis for sustainable entrepreneurship. Based on this, we present the following proposition: 
Proposition 3. In sustainable thinking, social and spatial context factors converge with a strong link in the identification of opportunity and a weak link in its exploitation, while institutional and business context factors have a strong link in the exploitation of opportunity and a weak link in its identification. This sustainable thinking leads to a stronger orientation towards sustainable entrepreneurship.

\subsection{Theoretical contributions}

Having outlined our propositions, we argue that in addition to markets, money, management, motherhood and meso- and macro-environment, Brush et al.'s (2009) 5M model of women's entrepreneurship, framed in institutional theory, should include "environmental thinking" as the 6th M. This complements the holistic nature of women's entrepreneurship, corroborated by the commitment they have shown in our case studies to sustainable entrepreneurship. Figure 4 presents the 6th M's cross-cutting level of interaction.

\section{Conclusion}

The need to better understand women's entrepreneurship and the effects of the influence of the social, spatial, institutional and market context has been strongly advocated. This research presents the singularities of women entrepreneurs in the Ecuadorian context; their search for a work-family balance and the vindication of their maternal role as they seek to achieve their professional development by creating businesses, even though their growth is limited by serving only local markets, having a small number of employees and little vision for growth and expansion. Many women entrepreneurs have identified business opportunities through their own experiences of motherhood and have exploited them with an optimistic perception of the market, launching their product to a segment to which they themselves belong, in line with the views of several authors (Shelton, 2006; Jennings and Brush, 2013; Thompson et al., 2009; Brush, 1992; Down and Warren, 2008; Ekinsmyth, 2011).

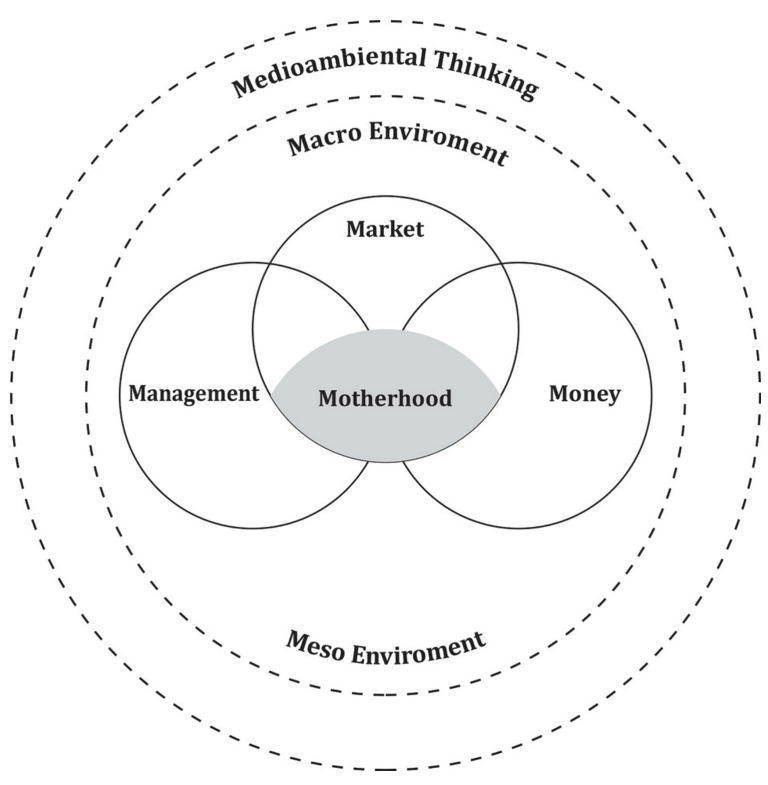

Figure 4. $6 \mathrm{M}$ Women entrepreneurship framework 
ARLA 34,3

\section{8}

They are also sensitive to the realities of their environment, showing great social and environmental concern, without leaving aside product innovation as part of their proposal to the market. Culture, an informal factor of the institutional context modelled by the social context, has motivated them to undertake entrepreneurship jointly with their partner, which has brought them the benefits of economic contribution, the team vision inside and outside the home, having a partner who they trust and easy division of functions.

Overall, our research contributes with a description of the deepest considerations of women entrepreneurs who live the Ecuadorian reality, which is replicated across Latin America, and characterised by a scarcity of adequate public policies.

We want to emphasise the importance of such articles in shaping public initiatives that, as shown by Foss et al. (2019), are appropriately oriented towards either entrepreneurship development or small business policies. Similarly, in line with Aldrich and Martinez (2001), we recommend that governments lift their gaze from research on the individual entrepreneur to address how process and context interact to provide the outcomes of entrepreneurial efforts. We also concur with liberal feminist theory in proposing structural change whereby male and female entrepreneurs have equal access to resources and equal access to entrepreneurial education and training. We emphasise the need for legislation that prohibits banks from requiring a husband's co-signature for a loan (Foss et al., 2019), and we urge governments to create institutions that provide adequate care for children, especially in societies such as Latin America where family roles influence women's entrepreneurial choices.

In terms of research, this study opens up some avenues for future studies. First, given that the study is based on a sample of Ecuadorian women entrepreneurs, the model could be replicated in samples corresponding to other territories, especially in Latin America, where the context is similar for women. This would test the generalisability of the results. Second, quantitative scales could be developed and applied in future research, which would make it possible to contrast the results obtained in this sense in the present study. Finally, extending the contextual framework of the " $5 \mathrm{M}$ " model with a "sixth M" complements the theory and opens up the option of studying new dimensions, such as green thinking, sustainable business and sustainable development.

We conclude by emphasising the broad conceptual and empirical potential offered by the topic of women's entrepreneurship, especially the study of the context that has been called for by authors such as Minniti and Naude (2010), De Vita et al. (2013), Kelley et al. (2015), Welter et al. (2014). These authors point out the limitations regarding the study of factors influencing the environment, in research on women's entrepreneurship, as we have demonstrated with this paper.

\section{Limitations}

The qualitative empirical study reveals a profound reality concerning the thinking of urban women entrepreneurs in the Ecuadorian context. Although we have tried to analyse the whole context through semi-structured interviews using questions from the GEM forms, this research could be extended by applying surveys to small representative samples, forming quantitative research that can be complemented with what has been studied. This would enable us to better understand the phenomenon of women's entrepreneurship, which, while widely analysed in African, Asian and Eastern European countries, has not been broadly examined in Latin America, where the struggle to vindicate the role of women and their contribution to the economy and the development of their communities is a topic of interest. This is especially true for areas where significant changes are being demanded in terms of women's inclusion. 
Ács, Z.J., Szerb, L. and Lloyd, A. (2018), GEI - the Global Entrepreneurship Index-2018, Global Entrepreneurship and Development Institute, available at: https://thegedi.org/ (accessed 30 entrepreneurship November 2017).

Aidis, R. (2016), "Three faces of innovation: institutions, gender and entrepreneurship in Latin America", in Alsos, G., Hytti, U. and Ljunggren, E. (Eds), Research handbook on gender and innovation, Edward Elgar Publishing, pp. 72-90, doi: 10.4337/9781783478132.00010.

Aldrich, H.E. and Martinez, M.A. (2001), "Many are called but few are chosen: an evolutionary perspective for the study of entrepreneurship", Entrepreneurship: Theory and Practice, Vol. 25 No. 4, pp. 41-56, doi: 10.1177/104225870102500404.

Alvarez, R. and Grazzie, M. (2018), "Innovation and entrepreneurship in Latin America: what do we know? What would we like to know?", Estudios de Economia, Vol. 45 No. 2, pp. 157-170.

Alvarez, C., Noguera, M. and Urbano, D. (2012), "Condicionantes del entorno y emprendimiento femenino. Un estudio cuantitativo en España”, Economia Industrial, Vol. 338, pp. 43-52.

Anderson, A., Dodd, S. and Jack, S. (2010), "Network practices and entrepreneurial growth", Scandinavian Journal of Management, Vol. 26 No. 2, pp. 121-133, doi: 10.1016/j.scaman.2010. 01.005 .

Ardichvili, A. and Cardozo, R.N. (2000), "A model of the entrepreneurial opportunity recognition process", Journal of Enterprising Culture, Vol. 0802, pp. 103-119, doi: 10.1142/ S0218495800000073.

Arenius, P. and Minniti, M. (2005), "Perceptual variables and nascent entrepreneurship", Small Business Economics, Vol. 243, pp. 233-247, doi: 10.1007/s11187-005-1984-x.

Arráiz, I. (2018), "Time to share the load: gender differences in household responsibilities and business profitability”, Small Business Economics, Vol. 51 No. 1, pp. 57-84, doi: 10.1007/s11187-017-9925-z.

Baines, S. and Wheelock, J. (1998), "Working for each other: gender, the household and micro-business survival and growth”, International Small Business Journal, Vol. 17 No. 1, pp. 16-35.

Baker, T. and Welter, F. (2018), "Contextual entrepreneurship: an interdisciplinary perspective", Foundations and Trends ${ }^{\circledR}$ in Entrepreneurship, Vol. 14 No. 4, pp. 357-426, doi: 10.1561/ 0300000078 .

Barnett, F. and Barnett, S. (1988), Working Together: Entrepreneurial Couples, Ten Speed Press, Berkley, CA.

Bird, B. and Brush, C. (2002), "A gendered perspective on organizational creation”, Entrepreneurship: Theory and Practice, Vol. 26 No. 3, pp. 41-65, doi: 10.1177/104225870202600303.

Blenkinsopp, J. and Owens, G. (2010), "At the heart of things", International Journal of Entrepreneurial Behaviour and Research, Vol. 16 No. 5, pp. 357-369, doi: 10.1108/13552551011071850.

Boettke, P.J. and Coyne, C.J. (2009), "Context matters: institutions and entrepreneurship", Foundations and Trends ${ }^{\circledR}$ in Entrepreneurship, Vol. 5 No. 3, pp. 135-209, doi: 10.1561/0300000018.

Boyd, R. and Richerson, P.J. (2009), "Culture and the evolution of human cooperation", Philosophical Transactions of the Royal Society B: Biological Sciences, Vol. 364 No. 1533, pp. 3281-3288, doi: 10. 1098/rstb.2009.0134.

Brush, C.G. (1992), "Research on women business owners: past trends, a new perspective and future directions", Entrepreneurship Theory and Practice, Vol. 4 No. 16, pp. 5-30.

Brush, C.G. (2014), "Exploring the concept of an entrepreneurship education ecosystem", in Hoskinson, S. and Kuratko, D. (Eds), Innovative Pathways for University Entrepreneurship in the 21st Century (Advances in the Study of Entrepreneurship, Innovation and Economic Growth), Emerald Group Publishing, Vol. 24, pp. 25-39, doi: 10.1108/S1048-473620140000024000.

Brush, C.G., De Bruin, A. and Welter, F. (2009), "A gender-aware framework for women's entrepreneurship", International Journal of Gender and Entrepreneurship, Vol. 11, pp. 8-24, doi: 10.1108/17566260910942318. 
ARLA 34,3
Brush, C., Greene, P., Balachandra, L. and Davis, A. (2018), "The gender gap in venture capitalprogress, problems, and perspectives”, Venture Capital, Vol. 20 No. 2, pp. 115-136, doi: 10.1080/ 13691066.2017.1349266.

Carter, S.L., Anderson, S. and Shaw, E. (2001), "Women's business ownership: a review of the academic, popular and internet literature”, Report: Small Business Service Research Report (2001).

Ciegis, R., Ramanauskiene, J. and Martinkus, B. (2009), "The concept of sustainable development and its use for sustainability scenarios", Engineering Economics, Vol. 62 No. 2, pp. 28-37.

Davidsson, P. and Honig, B. (2003), "The role of social and human capital among nascent entrepreneurs", Journal of Business Venturing, Vol. 18 No. 3, pp. 301-331, doi: 10.1016/S08839026(02)00097-6.

De Carolis, D.M., Litzky, B.E. and Eddleston, K.A. (2009), "Why networks enhance the progress of new venture creation: the influence of social capital and cognition", Entrepreneurship: Theory and Practice, Vol. 33 No. 2, pp. 527-545, doi: 10.1111/j.1540-6520.2009.00302.x.

De Vita, L., Mari, M. and Poggesi, S. (2013), "Female entrepreneurship research: a classification of results", in Caferata, R. (Ed.), Essays in Management, Economics \& Ethics, Mc. Graw Hill, No. 26, pp. 3-26.

Down, S. and Warren, L. (2008), "Constructing narratives of enterprise: clichés and entrepreneurial self-identity", International Journal of Entrepreneurial Behavior and Research, Vol. 14 No. 1, pp. 4-23, doi: 10.1108/13552550810852802.

Duberley, J. and Carrigan, M. (2012), “The career identities of 'mumpreneurs': women's experiences of combining enterprise and motherhood", International Small Business Journal, Vol. 31 No. 6, pp. 629-651, doi: 10.1177/0266242611435182.

Eikhof, R., Summers, J. and Carter, S. (2013), "Women doing their own thing: media representations of female entrepreneurship", International Journal of Entrepreneurial Behaviour and Research, Vol. 19 No. 5, pp. 547-564, doi: 10.1108/IJEBR-09-2011-0107.

Eisenhardt, K.M. and Graebner, M.E. (2007), “Theory building from cases: opportunities and challenges”, Academy of Management Journal, Vol. 50 No. 1, pp. 25-32, doi: 10.5465/amj.2007.24160888.

Ekinsmyth, C. (2011), "Challenging the boundaries of entrepreneurship: the spatialities and practices of UK 'Mumpreneurs”, Geoforum, Vol. 42 No. 1, pp. 104-114, doi: 10.1016/j.geoforum.2010.10.005.

Foss, L., Henry, C., Ahl, H. and Mikalsen, G.H. (2019), "Women's entrepreneurship policy research: a 30-year review of the evidence", Small Business Economics, Vol. 53 No. 2, pp. 409-429, doi: 10. 1007/s11187-018-9993-8.

Gallo, P.J., Antolin-Lopez, R. and Montiel, I. (2018), "Associative sustainable business models: cases in the bean-to-bar chocolate industry", Journal of Cleaner Production, Vol. 174, pp. 905-916, doi: 10. 1016/j.jclepro.2017.11.021.

García-Campos, T. (2008), "Cultura tradicional y masculinidad feminidad”, Interamerican Journal of Psychology, Vol. 42 No. 1, pp. 59-68.

GEM (2018), “GEM 2017/2018 global report”, Global Entrepreneurship Research Association, London, available at: https://www.gemconsortium.org/report/gem-2017-2018-global-report (accessed 19 October 2019).

Gibbert, M. and Ruigrok, W. (2010), “The 'what' and 'how' of case study rigor: three strategies based on published work", Organizational Research Methods, Vol. 13 No. 4, pp. 710-737, doi: 10.1177/ 1094428109351319.

Gibson-Graham, J.K. (1996), “Querying globalization”, Rethinking Marxism, Vol. 9 No. 1, pp. 1-27, doi: $10.1080 / 08935699608685474$.

Granato, J., Inglehart, R. and Leblang, D. (1996), "The effect of cultural values on economic development: theory, hypotheses, and some empirical tests", American Journal of Political Science, Vol. 403, pp. 607-631, doi: 10.2307/2111786. 
Gurstein, P. (1996), "Planning for telework and home-based employment: reconsidering the home/work separation", Journal of Planning Education and Research, Vol. 15 No. 3, pp. 212-224, doi: 10. 1177/0739456X9601500305.

Hammer, T.H., Saksvik, P., Nytro, K., Torvatn, H. and Bayazit, M. (2004), "Expanding the psychosocial work environment: workplace norms and work-family conflict as correlates of stress and health", Journal of Occupational Health Psychology, Vol. 9 No. 1, pp. 83-97, doi: 10.1037/10768998.9.1.83.

Harrison, R.T., Leitch, C.M. and McAdam, M. (2020), "Woman's entrepreneurship as a gendered niche: the implications for regional development policy”, Journal of Economic Geography, Vol. 20 No. 4, pp. 1-27, doi: 10.1093/jeg/lbz035.

Hechavarria, D.M. (2016), "The impact of culture on national prevalence rates of social and commercial entrepreneurship", International Entrepreneurship and Management Journal, Vol. 12 No. 4, pp. 1025-1052, doi: 10.1007/s11365-015-0376-1.

Hechavarria, D.M., Ingram, A., Justo, R. and Terjesen, S. (2012), “Are women more likely to pursue social and environmental entrepreneurship”, Hughes, K. and Jennings, J. (Eds), Global Women's Entrepreneurship Research: Diverse Settings, Questions and Approaches, Edward Elgar Publishing, pp. 135-151, doi: 10.4337/9781849804752.00016.

Heller, L. (2012), "Diversidad de Género en las Organizaciones: Empresas globales, culturas locales", Doctoral dissertation, Tesis Doctoral, Universidad de Buenos Aires. FCE, available at: http:// www.econ.uba.ar/www/servicios/Biblioteca/bibliotecadigital/bd/tesis_doc/heller. pdf (accessed 10 October 2020).

Herron, L. and Robinson, R.B. Jr (1993), "A structural model of the effects of entrepreneurial characteristics on venture performance", Journal of Business Venturing, Vol. 8 No. 3, pp. 281-294, doi: 10.1016/0883-9026(93)90032-Z.

Hofstede, G. (1983), "National cultures in four dimensions: a research-based theory of cultural differences among nations", International Studies of Management and Organization, Vol. 13, pp. 146-274, doi: 10.1080/00208825.1983.11656358.

Hofstede, G. and McCrae, R.R. (2004), "Personality and culture revisited: linking traits and dimensions of culture”, Cross-Cultural Research, Vol. 38 No. 1, pp. 52-88, doi: 10.1177/1069397103259443.

Instituto Nacional de Etadísticas y Censos - INEC (2019), "Encuesta Nacional de Empleo, Desempleo y Subempleo (ENEMDU)", available at: https://www.ecuadorencifras.gob.ec/documentos/webinec/EMPLEO/2019/Septiembre/201909_Mercado_Laboral.pdf (accessed 30 October 2019).

Jack, S.L. and Anderson, A.R. (2002), "The effects of embeddedness on the entrepreneurial process", Journal of Business Venturing, Vol. 17 No. 5, pp. 467-487, doi: 10.1016/S0883-9026(01)00076-3.

Jack, S., Dodd, S.D. and Anderson, A.R. (2008), "Change and the development of entrepreneurial networks over time: a processual perspective", Entrepreneurship and Regional Development, Vol. 20 No. 2, pp. 125-159, doi: 10.1080/08985620701645027.

Jambor, E. and Lindner, J.Y. (2018), “TRIO model for entrepreneurship education”, available at: www. youthstart.eu (accessed 11 de 2019 de 2018).

Jennings, J.E. and Brush, C.G. (2013), "Research on women entrepreneurs: challenges to (and from) the broader entrepreneurship literature?", The Academy of Management Annals, Vol. 7 No. 1, pp. 663-715, doi: 10.5465/19416520.2013.782190.

Johns, G. (2006), "The essential impact of context on organizational behavior", Academy of Management Review, Vol. 31 No. 2, pp. 386-408, doi: 10.5465/amr.2006.20208687.

Johns, G. (2017), "Reflections on the 2016 decade award: incorporating context in organizational research", Academy of Management Review, Vol. 42 No. 4, pp. 577-595, doi: 10.5465/amr.2017. 0044Invited.

Johnson, M.P. and Schaltegger, S. (2020), "Entrepreneurship for sustainable development: a review and multilevel causal mechanism framework", Entrepreneurship: Theory and Practice, Vol. 44 No. 6, pp. 1-33, doi: 10.1177/1042258719885368. 
ARLA 34,3
Johnson, G., Melin, L. and Whittington, R. (2003), "Micro strategy and strategizing: towards an activity-based view", Journal of Management Studies, Vol. 40 No. 1, pp. 3-22, doi: 10.1111/14676486.t01-2-00002.

Jurik, N.C., Křřžková, A., Pospíśilová, M. and Cavender, G. (2019), "Blending, credit, context: doing business, family and gender in Czech and US copreneurships", International Small Business Journal, Vol. 37 No. 4, pp. 317-342, doi: 10.1177/0266242618825260.

Kelley, D., Brush, C., Greene, P., Herrington, M., Ali, A. and Kew, P. (2015), "GEM special report: women's entrepreneurship 2015”, Global Entrepreneurship Research Association, available at: https://gemorg.bg/reports/special-topic-reports/gem-2015-women-s-report/ (accessed 19 December 2019).

Kelley, D., Baumer, B., Brush, C., Greene, P., Mahdavi, M., Majbouri, M., Cole, M., Dean, M. and Heavlow, R. (2017), "Global entrepreneurship monitor 2016/2017 report on women's entrepreneurship", Global Entrepreneurship Research Association, available at: https://www. gemconsortium.org/report/gem-20162017-womens-entrepreneurship-report (accessed 10 September 2019).

Khan, M. (2019), "Dynamics encouraging women towards embracing entrepreneurship: case Study of MENA countries", International Journal of Gender and Entrepreneurship, Vol. 11 No. 4, pp. 379-389, doi: 10.1108/IJGE-01-2019-0017.

King, N. (2004), "Using templates in the thematic analysis of text", in Cassell, C. and Symon, G. (Eds), Essential Guide to Qualitative Methods in Organizational Research, Sage Publications, London, pp. 256-270.

Kostova, T. (1997), "Country institutional profiles: concept and measurement", Academy of Management Proceedings, No. 1, pp. 180-184, doi: 10.5465/ambpp.1997.4981338.

Lago, I. (2002), "La discriminación salarial por razones de género: un análisis empírico del sector privado en España”, Reis, Vol. 98, pp. 171-196.

Lamas, M. (2008), "El aborto en la agenda del desarrollo en América Latina", Perfiles Latinoamericanos, Vol. 16 No. 31, pp. 65-93.

Langowitz, N. and Minniti, M. (2007), "The entrepreneurial propensity of women”, Entrepreneurship: Theory and Practice, Vol. 31 No. 3, pp. 341-364, doi: 10.1111/j.1540-6520.2007.00177.x.

Larty, J. and Hamilton, E. (2011), "Structural approaches to narrative analysis in entrepreneurship research: exemplars from two researchers", International Small Business Journal, Vol. 29 No. 3, pp. 220-237, doi: 10.1177/0266242611401796.

Lasio, V., Ordeñana, X., Caicedo, G., Samaniego, A. and Izquierdo, E. (2018), "Global entrepreneurship monitor Ecuador 2017”, ESPAE Graduate School of Management - ESPOL, available at: http:// espae.espol.edu.ec/wp-content/uploads/documentos/GemEcuador2017.pdf (accessed 16 August 2018).

Li, Y., Wang, P. and Liang, Y.J. (2015), "Influence of entrepreneurial experience, alertness, and prior knowledge on opportunity recognition", Social Behavior and Personality: An International Journal, Vol. 43 No. 9, pp. 1575-1583, doi: 10.2224/sbp.2015.43.9.1575.

Loprest, P.J. (1992), "Gender differences in wage growth and job mobility", The American Economic Review, Vol. 82 No. 2, pp. 526-532.

Machek, O. and Hnilica, J. (2015), "Copreneurship and its impact on financial characteristics of companies”, Ekonomický časopis, Vol. 63 No. 2, pp. 152-156.

Man, T.W.Y. and Lau, T. (2005), "The context of entrepreneurship in Hong Kong: an investigation through the patterns of entrepreneurial competencies in contrasting industrial environments", Journal of Small Business and Enterprise Development, Vol. 12 No. 4, pp. 464-481, doi: 10.1108/ 14626000510628162.

Mandakovic, V., Romani, G., Santander, P., Serey, T. and Soria, K. (2017), "Mujeres y actividad emprendedora en Chile 2017", Global Entrepreneurship Monitor, available at: https://repositorio. udd.cl/handle/11447/2311 (accessed 15 March 2018). 
Manolova, T.S., Eunni, R.V. and Gyoshev, B.S. (2008), "Institutional environments for entrepreneurship: evidence from emerging economies in Eastern Europe", Entrepreneurship: Theory and Practice, Vol. 32 No. 1, pp. 203-218, doi: 10.1111/j.1540-6520.2007.00222.x.

Martín-Ugedo, J.F., Mínguez-Vera, A. and Rossi, F. (2019), "Female directors and firm performance in Italian and Spanish listed firms: does masculinity matter?", Academia. Revista Latinoamericana de Administración, Vol. 323, pp. 411-436, doi: 10.1108/ARLA-06-2018-0124.

McGrath, R. and McMillan, I. (1992), "More like each other than anyone else? A cross-cultural study of entrepreneurial perceptions", Journal of Business Venturing, Vol. 7 No. 5, pp. 419-429, doi: 10. 1016/0883-9026(92)90017-L.

Minniti, M. (2009), "Gender issues in entrepreneurship", Foundations and Trends ${ }^{\circledR}$ in Entrepreneurship, Vol. 5, pp. 7497-8621, doi: 10.1561/0300000021.

Minniti, M. and Arenius, P. (2003), "Women in entrepreneurship", En: The Entrepreneurial Advantage of Nations: First Annual Global Entrepreneurship Symposium, United Nations Headquarters, Vol. 29, pp. 1-28, April 29, 2003.

Minniti, M. and Naudé, W. (2010), "What do we know about the patterns and determinants of female entrepreneurship across countries?", European Journal of Development Research, Vol. 22, pp. 227-293, doi: 10.1057/ejdr.2010.17.

Minniti, M., Arenius, P. and Langowitz, N. (2005), "GEM 2004 report on women and entrepreneurship", Centre for Women's Leadership at Babson College/London Business School, available at: https:// www.findevgateway.org/sites/default/files/publications/files/mfg-en-paper-gem-2004-report-onwomen-and-entrepreneurship-2005_0.pdf (accessed 20 January 2019).

Mowday, R. and Sutton, R. (1993), "Organizational behavior: linking individuals and groups to organizational contexts", Annual Review of Psychology, Vol. 44, pp. 195-229.

Muñoz, P. and Cohen, B. (2018), "Sustainable entrepreneurship research: taking stock and looking ahead", Business Strategy and the Environment, Vol. 27 No. 3, pp. 300-322, doi: 10.1002/bse.2000.

Naguib, R. and Jamali, D. (2015), "Female entrepreneurship in the UAE: a multi-level integrative lens", Gender in Management: International Journal, Vol. 30 No. 2, 2015, pp. 135-161, doi: 10.1108/GM12-2013-0142.

North, D.C. (1997), “The process of economic change", Working paper, World Institute for Development Economics Research, March 1997.

Palomar Verea, C. (2005), "Maternidad: historia y cultura. La ventana”, Revista de estudios de género, Vol. 3 No. 22, pp. 35-67.

Quevedo, L.M., Izar, J.M. and Romo, R.L. (2010), "Factores endógenos y exógenos de mujeres y hombres emprendedores de España, Estados Unidos y México", Investigación y Ciencia, Vol. 18 No. 46, pp. 57-63.

Reynolds, P., Storey, D.J. and Westhead, P. (1994), "Cross-national comparisons of the variation in new firm formation rates”, Regional Studies, Vol. 28 No. 4, pp. 443-456, doi: 10.1080/ 00343409412331348386.

Rosaldo, M.Z., Lamphere, L. and Bamberger, J. (1974), Woman, Culture, and Society, Stanford University Press, Stanford, CA, Vol. 133.

Rousseau, D.M. and Fried, Y. (2001), "Location, location, location: contextualizing organizational research", Journal of Organizational Behavior, Vol. 22 No. 1, pp. 1-13.

Rubio, A. and Esteban, N. (2016), "Cultural factors and gender role in female entrepreneurship", Suma de Negocios, Vol. 7, pp. 9-17, doi: 10.1016/j.sumneg.2015.12.002.

Ruiz-Arroyo, M.R., Fuentes-Fuentes, M. and Ruiz-Jiménez, J.M. (2017), "An international study of the factors explaining high-growth expectation in new ventures: a gender perspective", Revista brasileira de gestão de negócios, Vol. 18 No. 60, pp. 171-190, doi: 10.7819/rbgn.v18i60.1947.

Ruiz-Arroyo, M., Sanz-Espinosa, I. and Fuentes-Fuentes, M. (2015), "Alerta emprendedora y conocimiento previo para la identificación de oportunidades emprendedoras: el papel 
ARLA 34,3 moderador de las redes sociales", Investigaciones Europeas de Dirección y Economía de la Empresa, Vol. 21 No. 1, pp. 47-54, doi: 10.1016/j.iedee.2014.07.002.

Scott, W.R. (1995), "Institutions and organizations. Ideas, interests and identities", Paperback, Sage Management, Vol. 17 No. 2, pp. 136-140, doi: 10.3917/mana.172.0136.

Senplades (2017), "Plan Nacional de Desarrollo 2017-2021", Secretaría Nacional de Planificación y Desarrollo - Senplades 2017, available at: https://www.planificacion.gob.ec/wp-content/uploads/ downloads/2017/10/PNBV-26-OCT-FINAL_0K.compressed1.pdf (accessed 15 February 2020).

Shane, S.A. (2003), A General Theory of Entrepreneurship: The Individual-opportunity Nexus, Edward Elgar Publishing.

Shane, S. and Venkataraman, S. (2000), "The promise of entrepreneurship as a field of research", Academy of Management Review, Vol. 25 No. 1, pp. 217-226.

Shelton, L.M. (2006), "Female entrepreneurs, work-family conflict, and venture performance: new insights into the work-family interface", Journal of Small Business Management, Vol. 2 No. 44, pp. 285-297, doi: 10.1111/j.1540-627X.2006.00168.x.

Shepherd, D.A. and Patzelt, H. (2011), "The new field of sustainable entrepreneurship: studying entrepreneurial action linking 'what is to be sustained' with 'what is to be developed", Entrepreneurship: Theory and Practice, Vol. 35 No. 1, pp. 137-163, doi: 10.1111/j.1540-6520.2010. 00426.x.

Silverman, D. and Marvasti, A. (2008), Doing Qualitative Research: A Comprehensive Guide, Sage, Los Ángeles, LA.

Simpson, B. and Willer, R. (2008), "Altruism and indirect reciprocity: the interaction of person and situation in prosocial behavior", Social Psychology Quarterly, Vol. 71 No. 1, pp. 37-52, doi: 10. 1177/019027250807100106.

Steyaert, C. and Katz, J. (2004), "Reclaiming the space of entrepreneurship in society: geographical, discursive and social dimensions", Entrepreneurship and Regional Development, Vol. 16 No. 3, pp. 179-196, doi: 10.1080/0898562042000197135.

Strauss, A. and Corbin, J. (1990), Basics of Qualitative Research, Sage Publications, Berlin, doi: 10.5072/ genderopen-develop-7.

Taylor, S.J. and Bogdan, R. (1984), Introduction to Qualitative Research Methods: The Search for Meanings, Wiley-Interscience, Nueva York.

Thompson, P., Jones-Evans, D. and Kwong, C. (2009), "Women and home-based entrepreneurship: evidence from the United Kingdom", International Small Business Journal, Vol. 27 No. 2, pp. 227-239, doi: 10.1177/0266242608100492.

Tilley, F. and Young, W. (2009), "Sustainability entrepreneurs", Greener Management International, No. 55 , pp. 79-92.

Varela, R. (2001), "La cultura empresarial como estrategia de desarrollo para América Latina. Creación de empresas-Entrepreneurship"Creación de empresas - Entrepreneurship, pp. 1-22.

Waddington, D. (2004), "Participant observation", in En Cassells, C. and Symon, G. (Eds), Essential Guide to Qualitative Methods in Organizational Research, Sage Publications, London, pp. 154-265.

Wagner, S. and Rush, M. (2000), "Altruistic organizational citizenship behavior: context, disposition, and age", The Journal of Social Psychology, Vol. 140 No. 3, pp. 379-391, doi: 10.1080/ 00224540009600478.

Welter, F. (2004), "The environment for female entrepreneurship in Germany", Journal of Small Business and Enterprise Development, Vol. 11 No. 2, pp. 212-221, doi: 10.1108/ 14626000410537155.

Welter, F. (2011), "Contextualizing entrepreneurship - conceptual challenges and ways forward", Entrepreneurship: Theory and Practice, Vol. 35 No. 1, pp. 165-184, doi: 10.1111/j.1540-6520.2010. 00427.x. 
Welter, F. (2020), "Contexts and gender-looking back and thinking forward", International Journal of Gender and Entrepreneurship, Vol. 121, pp. 27-38, doi: 10.1108/IJGE-04-2019-0082.

Welter, F. and Trettin, L. (2006), "The spatial embeddedness of networks for women entrepreneurs", in Women Fritsch, M. and Schmude, J. (Eds), Entrepreneurship in the Region. International Studies in Entrepreneurship, Springer, Boston, MA, Vol. 14, doi: 10.1007/0-387-28376-5_3.

Welter, F. and Smallbone, D. (2008), "Women's entrepreneurship from an institutional perspective: the case of Uzbekistan", International Entrepreneurship and Management Journal, Vol. 4 No. 4 , pp. 505-520, doi: 10.1007/s11365-008-0087-y.

Welter, F., Smallbone, D., Aculai, E., Isakova, N. and Schakirova, N. (2003), "Female entrepreneurship in post Soviet countries", in Butler, J.E. (Ed.), New Perspectives on Women Entrepreneurs, Information Age Publishing, Conecticut, pp. 223-239.

Welter, F., Brush, C. and De Bruin, A. (2014), The Gendering of Entrepreneurship Context, Working paper, Institut für Mittelstandsforschung Bonn, Bon, January 29, 2015.

World Economic Forum (2018), “The global competitiveness report 2018”, in Schwab, K. (Ed.), World Economic Forum, available at: https://es.weforum.org/reports/the-global-competitveness-report2018 (accessed 23 May 2019).

Yin, R.K. (2017), Case Study Research and Applications: Design and Methods, Sage Publications.

Zahra, S.A. and Wright, M. (2011), "Entrepreneurship's next act", Academy of Management Perspectives, Vol. 4 No. 25, pp. 67-83, doi: 10.5465/amp.2010.0149.

Zahra, S.A., Wright, M. and Abdelgawad, S.G. (2014), "Contextualization and the advancement of entrepreneurship research", International Small Business Journal, Vol. 32 No. 5, pp. 479-500, doi: 10.1177/0266242613519807. 


\begin{tabular}{l} 
ARLA \\
34,3 \\
$\mathbf{3 9 6}$ \\
\hline
\end{tabular}

Table A1.

Summary of the cases studied (interviews)

\section{Appendix}

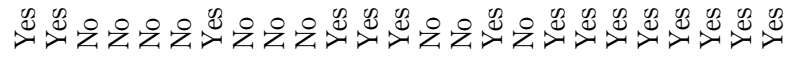

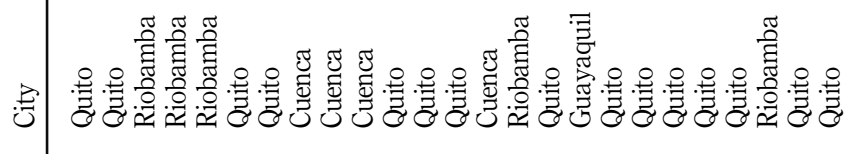
4 岁昰兽

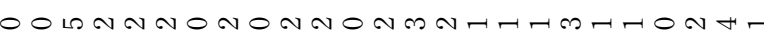

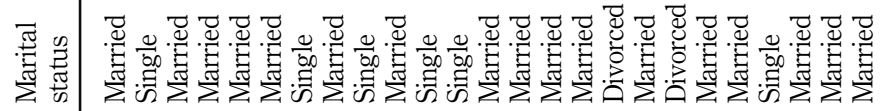
낭

ปั 言亮

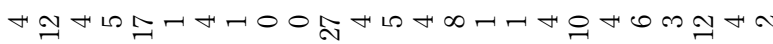
乙宁

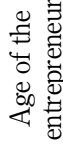

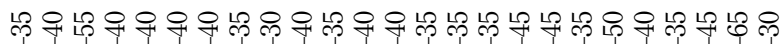

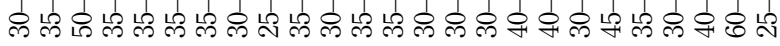

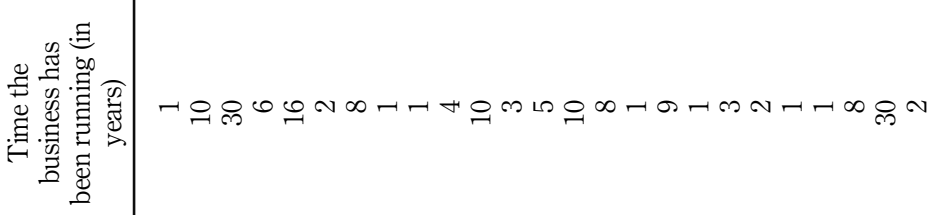

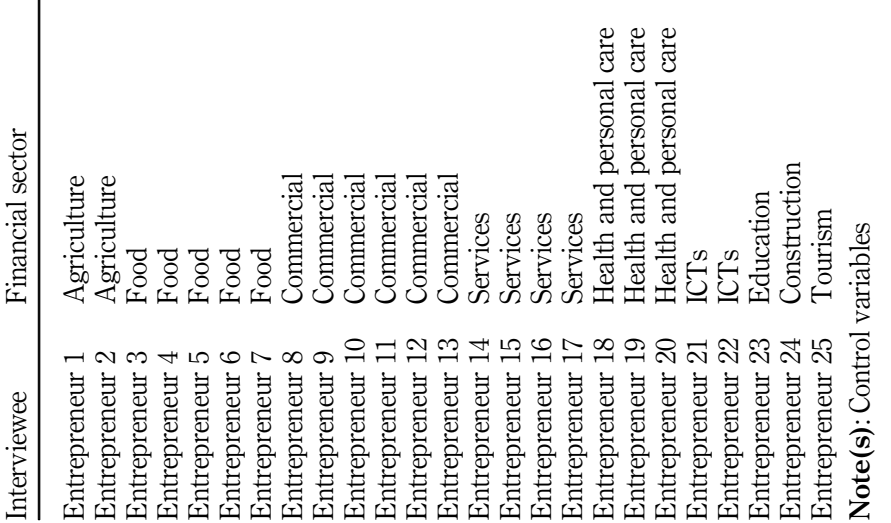




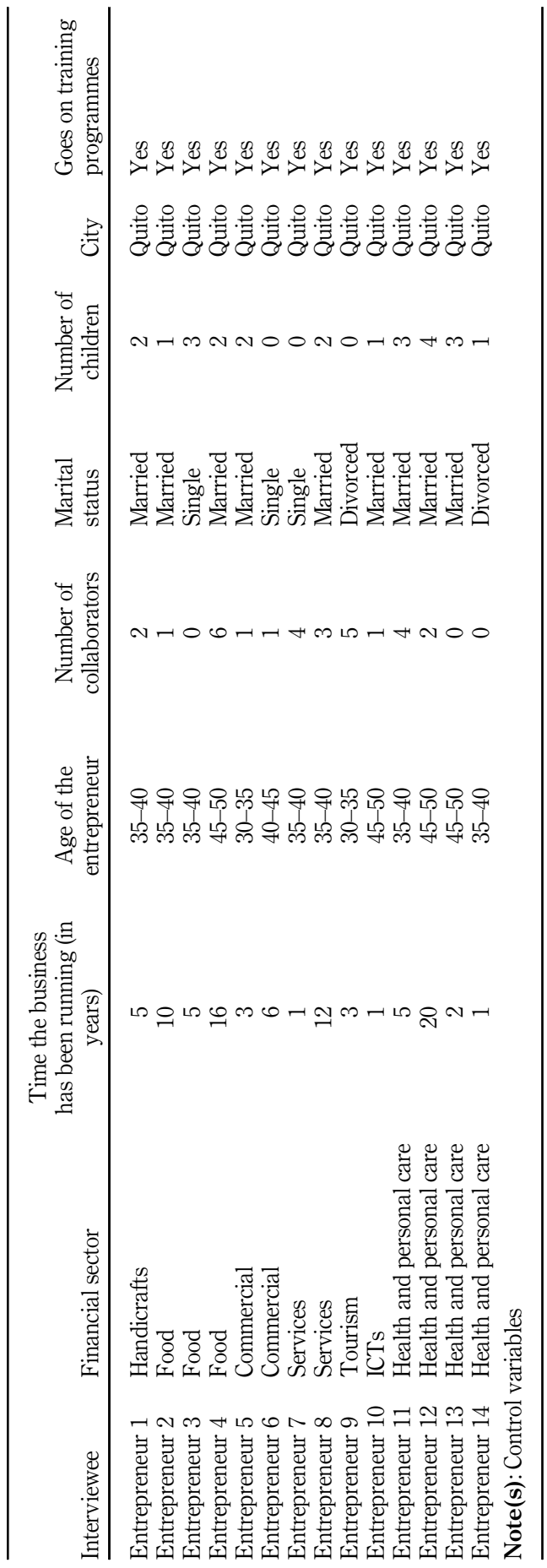

Women entrepreneurship

Table A2.

Summary of the cases studied (Focus group) 


\section{ARLA 34,3}

398

\begin{abstract}
About the authors
María Eulalia Chávez Rivera is a $\mathrm{PhD}$ candidate of Economic and Business Sciences from the University of Granada, and she has been a Teacher-Researcher at several universities in Ecuador. She has directed research programs in Development and Social Transformation and several research projects on Women's Entrepreneurship. She has several publications in academic journals. María Eulalia Chávez Rivera is the corresponding author and can be contacted at: mariaeulalia.chavez@udem.edu

María del Mar Fuentes Fuentes, PhD is Full Professor of Business Management of the University of Granada, specialized in Entrepreneurship, principal investigator of several publications in academics journals and research projects and responsible for the University of Granada of the International Project GUESSS (Global University Entrepreneurial Spirit Students Survey). She is currently a member of the Spanish Board of the Global Entrepreneurship Monitor Consortium (GEM), as director of the GEM projects for Granada and Melilla.

Jenny María Ruiz-Jiménez, PhD is Assistant Professor in the Department of Business Administration at the University of Granada, Spain. Her main research interests include entrepreneurship, women's entrepreneurship, gender diversity in organizations, firms' capabilities, innovation and the effectuation approach in entrepreneurship. She is co-author of several publications on these topics, including articles in Small Business Economics, Entrepreneurship \& Regional Development, Journal of Business Ethics, Business Research Quarterly and Industrial Management and Data System, among others.
\end{abstract}

For instructions on how to order reprints of this article, please visit our website: www.emeraldgrouppublishing.com/licensing/reprints.htm Or contact us for further details: permissions@emeraldinsight.com 